\title{
Robert Skobelski
}

Instytut Historii Uniwersytet Zielonogórski

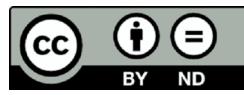

\section{Zagraniczne echa wyborów do Sejmu PRL z 20 stycznia 1957 roku}

Zarys treści: Tekst traktuje o zagranicznych echach wyborów sejmowych w PRL z 1957 roku. W bloku wschodnim kampania wyborcza i same wybory budziły niepokój, ponieważ pojmowano je jako ciąg dalszy przemian polskiego Października. Stąd też, pozytywne dla władz z Warszawy wyniki głosowania, przyjęto $z$ widoczną ulgą, podkreślając wagę wyborczego sukcesu PZPR. Inaczej wybory sejmowe w PRL interpretowano w innych państwach komunistycznych - Jugosławii i Chinach, dla których najistotniejsze w tym kontekście były własne interesy polityczne. Z kolei główne państwa Zachodu odbierały wydarzenia 1956 r. w Polsce, w tym wybory, przez głębszy pryzmat ówczesnych stosunków z blokiem wschodnim. Wyniki polskiego głosowania tłumaczono w kategoriach możliwości uzyskania większego marginesu swobody w relacjach PRL z ZSRR.

Outline of content: The article discusses the foreign echoes of the parliamentary elections in the Polish People's Republic in 1957. The electoral campaign and the elections themselves aroused concern throughout the Eastern Bloc, as they were interpreted as a continuation of the Polish October Revolution. The outcome of the vote, which proved satisfying for the authorities in Warsaw, was received with obvious relief; the importance of the electoral success of the Polish United Workers' Party was strongly emphasised. But some communist governments, namely those of Yugoslavia and China, demonstrated a different attitude, as they interpreted these results in the light of their own political interests. At the same time, major Western countries perceived the Polish events of 1956, including the elections, in a wider context of current relations with the Eastern Bloc. The results of the vote were cited as an opportunity for Poland to obtain a greater margin of liberty in its cooperation with the USSR.

Słowa kluczowe: wybory parlamentarne 1957, PRL, kampania wyborcza, stosunki międzynarodowe

Keywords: october elections 1957 in Poland, polish parliament, election campaign in Poland, international relations

Odwilż polityczna, którą w Polsce przyspieszyły „rewelacje” XX Zjazdu KPZR oraz śmierć Bolesława Bieruta, przyniosła również postulaty zwiększenia rzeczywistej roli 
Sejmu i zdemokratyzowania ordynacji wyborczej. Począwszy od wiosny 1956 r. - jak pisze Paweł Machcewicz - domagano się zarówno na łamach prasy, jak i w rezolucjach uchwalanych przez organizacje partyjne, aby parlament przestał być jedynie instytucją fasadową, a stanowił forum ścierania się różnych poglądów i stanowisk, przede wszystkim zaś narzędziem konstytucyjnej kontroli nad władzą wykonawczą ${ }^{1}$.

Z konieczności zmian w funkcjonowaniu i sposobie wyłaniania Sejmu zdawali sobie sprawę niektórzy przedstawiciele władz, zwłaszcza w obliczu narastającego fermentu społecznego i wzbierającego kryzysu politycznego. We fragmencie uchwały VII plenum KC PZPR, zwołanego w lipcu 1956 r. w ciężkiej atmosferze po wydarzeniach poznańskich, stwierdzano, że „Podniesienie roli Sejmu i zapewnienie pełnego wykonania przezeń jego konstytucyjnych zadań musi się stać składowa częścią demo-

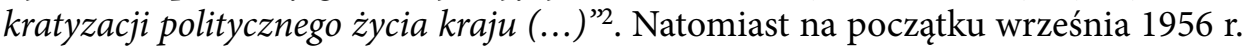
międzywydziałowa komisja KC do spraw Sejmu przedstawiła kilka wariantów zmian korygujących w różnym zakresie dotychczasową ordynację wyborczą. Równolegle toczono dyskusje nad terminem głosowania. Coraz wyraźniej przeważały opinie, że konstytucyjna data wyborów, przypadająca na 16 grudnia, musi zostać przesunięta. Argumentowano, że w sytuacji społecznego i politycznego wrzenia, pozwoliłoby to na lepsze przygotowanie zarówno nowej ordynacji, jak i kampanii wyborczej ${ }^{3}$.

Kwestia wyborów, ordynacji wyborczej i kształtu Sejmu stanowiła ważny element debaty i uchwały przełomowego VIII plenum KC PZPR w dniach 19-21 października 1956 roku. Kierownictwo partyjne deklarowało wówczas, że „Sejm musi w petni korzystać ze swych konstytucyjnych praw wszechstronnej kontroli pracy rzadu (...). Wybory będa przeprowadzone na takich zasadach, aby wyborcy wypowiadali się i decydowali nie tylko $w$ sprawie programu wyborczego, jak to było dotychczas, lecz także mieli możność wyboru między kandydatami, stanowienia o tym, kto i jak będzie ten program $w$ Sejmie realizować"'. Jeszcze przed plenum, 17 października, na posiedzeniu Biura Politycznego - już z udziałem Władysława Gomułki - rozstrzygnięto ostatecznie o odłożeniu głosowania na 20 stycznia $1957 \mathrm{roku}^{5}$. Kilka dni później, 24 października, Sejm uchwalił nową ordynację wyborczą, która przewidywała umieszczenie na liście kandydatów większej - najwyżej jednak o dwie trzecie - liczby nazwisk w stosunku do liczby mandatów przypadających na dany okręg.

1 Kampania wyborcza i wybory do Sejmu 20 stycznia 1957, wybór, wstęp i opracowanie P. Machcewicz, Warszawa 2000, s. 5.

2 Uchwała VII Plenum KC PZPR o sytuacji politycznej i gospodarczej kraju i zadaniach partii, [w:] Dokumenty programowe polskiego ruchu robotniczego 1878-1984, red. N. Kołomejczyk, B. Syzdek, Warszawa 1986, s. 4; L. Mażewski, Dyskusja na temat reformy ustroju Polskiej Rzeczypospolitej Ludowej w latach 1956-1957, „Czasopismo Prawno-Historyczne” 2010, z. 1, s. 226.

3 Kampania wyborcza i wybory..., s. 6.

4 Uchwała VIII Plenum KC PZPR z 21 października 1956 r. O aktualnych zadaniach politycznych i gospodarczych partii, [w:] Dokumenty programowe..., s. 505-506.

5 Protokół Nr 127 posiedzenia Biura politycznego w dniu 17 października 1956 r., [w:] Centrum władzy Protokoły posiedzeń kierownictwa PZPR. Wybór z lat 1949-1970, „Dokumenty do dziejów PRL”, oprac. A. Dudek, A. Kochański, K. Persak, Warszawa 2000, z. 13, s. 207. 
Oczywiście partia zachowywała kontrolę nad doborem kandydatów na przyszłych posłów, co umożliwiała jedna wspólna lista Frontu Jedności Narodu oraz wcześniejsze ustalenie podziału mandatów (PZPR miała zagwarantowane ponad 50\% miejsc w Sejmie) ${ }^{6}$.

Do drugiej połowy grudnia $1956 \mathrm{r}$. temat wyborów jedynie z rzadka pojawiał się w doniesieniach prasowych czy publicznych dyskusjach. Społeczną uwagę przykuwały w tym czasie bardziej wydarzenia na Węgrzech, relacje polsko-radzieckie i zmiany w strukturach władzy. Dopiero przed samymi świętami Bożego Narodzenia, a zwłaszcza po Nowym Roku, kampania wyborcza nabrała tempa przynosząc rzeczywistą rywalizację między kandydatami do parlamentu. Na zebraniach przedwyborczych toczono nieraz zażarte spory atakując szczególnie działaczy PZPR, których oskarżano o błędy okresu stalinowskiego. Burzliwy charakter kampanii, toczącej się jeszcze w klimacie przełomu październikowego, groził masowym skreślaniem kandydatów partyjnych uznawanych powszechnie za przeciwników dalszej demokratyzacji. Władze zareagowały w tej sytuacji apelem Gomułki o głosowanie bez skreśleń ( $w$ tym wypadku do parlamentu wchodzili kandydaci z pierwszych miejsc list) oraz uzyskały wsparcie dla wyborów ze strony Kościoła katolickiego (spotkanie premiera Józefa Cyrankiewicza z prymasem Stefanem Wyszyńskim) ${ }^{7}$.

W dniu wyborów spośród ponad 700 kandydatów wszędzie, poza jedynym przypadkiem z Nowego Sącza (tutaj głosowanie powtórzono w marcu 1957 r.), wybrano osoby z tzw. miejsc mandatowych. Frekwencja, według oficjalnych danych, wyniosła 94,14\% uprawnionych do głosowania, z czego 98,40\% poparło kandydatów FJN. Przebieg i rezultaty wyborów okazały się sukcesem nowej ekipy władzy na czele z Gomułką, który dzięki temu ugruntowywał - również wobec zagranicy - swój status niekwestionowanego przywódcy państwa. Wybory w PRL - jak zauważył Andrzej Leon Sowa - wykazały po raz pierwszy, że władza komunistyczna, postrzegana dotąd przez większość społeczeństwa jako obca i narzucona, została w pewnym sensie (i specyficznych okolicznościach) zalegalizowana i nie była już negowana tak emocjonalnie jak w latach poprzednich ${ }^{8}$.

Kampanii wyborczej i samym wyborom przyglądano się oczywiście poza granicami PRL - szczególnie uważnie w ZSRR i w pozostałych państwach radzieckiej strefy dominacji. Rozwój wydarzeń w Polsce już zresztą od dawna budził duże obawy: oddźwięk tajnego referatu Chruszczowa na XX Zjeździe KPZR, narastanie napięcia społecznego, rozdzierające partię walki frakcyjne i czerwcowa rewolta w Poznaniu. Zaniepokojenie Kremla sytuacją w PRL osiągnęło szczyt w okresie

6 Z. Pełczyński, Polska droga od komunizmu. Refleksje nad historia i polityka 1956-2006, Warszawa 2007, s. 88; R. Kraczkowski, Sejm w okresie PRL, [w:] Dzieje Sejmu Polskiego, Warszawa 2011, s. 249-250; T. Mołdawa, Sejm Polskiej Rzeczypospolitej Ludowej, [w:] Historia sejmu polskiego, t. III: Polska Ludowa, red. A. Ajnenkiel, Warszawa 1989, s. 162.

7 A. Friszke, Polska. Losy państwa i narodu 1939-1989, Warszawa 2003, s. 229; J. Żaryn, Dzieje Kościoła katolickiego w Polsce (1944-1989), Warszawa 2003, s. 176; E. i B. Syzdkowie, Cyrankiewicz. Zanim zostanie zapomniany, Warszawa 1996, s. 213-214.

8 A. L. Sowa, Historia polityczna Polski 1944-1991, Kraków 2011, s. 262. 
października, kiedy na wieść o zwołaniu VIII Plenum KC PZPR i przejmowaniu steru rządów w partii przez Gomułkę zdecydowano się na interwencję polityczną i militarną. Dalszej eskalacji kryzysu udało się jednak uniknąć, o czym przesądziła stanowczość, ale i rozwaga nowego I sekretarza, który, nie zapominając o położeniu swego kraju względem Moskwy, zdołał w znacznej mierze przekonać Chruszczowa o swojej sojuszniczej i ideologicznej lojalności9

Po Październiku władze ZSRR starały się unikać jawnej ingerencji w polskie sprawy wewnętrzne i godziły się milcząco na wiele niezależnych działań i posunięć politycznych kierownictwa PZPR. Nie oznaczało to zupełnego wyrzeczenia się przez Kreml stosowania różnych form nacisku czy choćby, znanego z okresu stalinowskiego, mentorskiego tonu. Odnosiło się to szczególnie do tych elementów rzeczywistości PRL, które z punktu widzenia przywódców KPZR zakłócały nadmiernie ideologiczny porządek, jaki starano się przywrócić w bloku wschodnim po 1956 roku. Znamienne w tym kontekście wydają się częste pretensje strony radzieckiej, wyrażane przy różnych okazjach, że Polska nie uznaje kierowniczej roli ZSRR i KPZR w obozie socjalistycznym i unika akcentowania tego faktu w oficjalnych wystąpieniach ${ }^{10}$.

Władze na Kremlu były zaniepokojone - niespotykaną przecież wcześniej w krajach „demokracji ludowej” - atmosferą i przebiegiem kampanii wyborczej. Szczególne rozdrażnienie Moskwy wzbudzały doniesienia o stale narastających nastrojach antyradzieckich. Do ambasady ZSRR docierały informacje o licznych wypowiedziach, ulotkach, napisach na murach czy nawet wystąpieniach niektórych kandydatów na posłów, którzy na spotkaniach z wyborcami krytykowali stan wzajemnych stosunków i wspominali o własnych, negatywnych doświadczeniach pobytu w Związku Radzieckim ${ }^{11}$.

Według kierownictwa radzieckiego, w Polsce szczególną aktywność w trakcie kampanii wyborczej wykazywały elementy wrogie i oportunistyczne, które widziano wśród części dziennikarzy, pisarzy, studentów, byłych działaczy Polskiego Stronnictwa Ludowego, członków Armii Krajowej itd. ${ }^{12}$ Niezadowolenie budziły listy wyborcze, ponieważ - jak dowodzono - znalazło się na nich szereg osób występujących $\mathrm{z}$,jawnie antypartyjnych pozycji”, jak Władysław Machejek (redaktor naczelny krakowskiego tygodnika „Życie Literackie”) i Eligiusz Lasota (kierujący redakcją tygodnika „Po prostu”), oraz „budzacych wątpliwości”, jak Jerzy Putrament, Helena

9 Utrzymanie Polski w bloku wschodnim stanowiło dla Gomułki podstawę realizacji jego własnej koncepcji polskiej racji stanu osadzonej na dwóch głównych podstawach. Pierwsza wynikała z niewzruszonych przekonań przywódcy PZPR jako komunisty, widzącego w sile i pomocy Kremla konieczne zabezpieczenie stabilności ustroju socjalistycznego w PRL. Natomiast druga wiązała się $\mathrm{z}$ gwarancjami ZSRR dla granicy zachodniej.

10 Z Raportu Ambasadora PRL w Moskwie Tadeusza Gedego za okres od 1 II-31 VII 1957 r. $z 9$ sierpnia 1957 r., [w:] A. Korzon, Pierwszy Raport Ambasadora PRL w Moskwie Tadeusza Gedego (1957 r.), „Dzieje Najnowsze” 1999, nr 4, s. 127; Archiwum Ministerstwa Spraw Zagranicznych (dalej: AMSZ), zespół (dalej: z.) 12, w. 4, t. 84, Notatka z rozmowy z II sekretarzem Ambasady ZSRR w Pekinie Rachmaninem, dnia 18. IV. 1957 r., k. 13.

11 AMSZ, z. 28, w. 7, t. 70, Notatka z rozmów z tow. Iliczowem, k. 29.

12 M. Szumiło, Roman Zambrowski 1909-1977. Studium z dziejów elity komunistycznej w Polsce, Warszawa 2014, s. 373-374. 
Jaworska i Julian Hochfeld. Zabrakło natomiast miejsc na listach dla „szczerych przyjaciół ZSRR", których na Kremlu widziano wśród członków konserwatywnej grupy natolińskiej, m.in. w Wiktorze Kłosiewiczu, Stanisławie Łapocie, Zenonie Nowaku, Franciszku Jóźwiaku czy Kazimierzu Witaszewskim. Jednocześnie za destabilizację sytuacji politycznej w tym czasie oskarżano Józefa Cyrankiewicza, Władysława Matwina, Jerzego Morawskiego i Romana Zambrowskiego, którzy jakoby „pobłażali wrogim wystapieniom elementów reakcyjnych, a nawet prowokowali ich do tego"13.

$\mathrm{W}$ tym kontekście krytykowano polską prasę, w której - zdaniem strony radzieckiej - pojawiały się poglądy antysocjalistyczne i która nie angażowała się wystarczająco podczas kampanii wyborczej w promowanie linii politycznej PZPR. Mówił o tym 12 stycznia ambasador ZSRR Pantelejmon Ponomarienko podczas spotkania z przedstawicielami prasy i władzami Stowarzyszenia Dziennikarzy Polskich. Dyplomata radziecki stwierdził: „Teraz na przykład zbliżaja się wybory. Nie ma dziś większego zadania jak obrona pozycji partii. Nie ma większego zadania dla prasy. A tymczasem wy zajmujecie się różnymi sprawami międzynarodowymi itd. itd., a wybory sa na dalszym planie. Zostało wam tylko siedem dni"14.

Przebieg i wyniki wyborów w znacznym stopniu uspokoiły Moskwę i wpłynęły na bardziej przychylne stanowisko wobec Warszawy ${ }^{15}$. „Prawda” (organ prasowy KC KPZR) pisała na przykład, „iż wybory wykazały, że wyborcy polscy rozumieja swą odpowiedzialność za losy kraju”. Dziennik „Izwiestia” zauważał z kolei: „Wybory świadcza wymownie, że naród polski nie uległ wplywom demagogów" i popiera politykę budowy socjalizmu, wytyczoną przez PZPR. Wybory wykazały także, „że większość narodu polskiego zdecydowanie wypowiada się za polityka przyjaźni ze Związkiem Radzieckim i innymi krajami socjalistycznymi"16.

Oficjalny pozytywny odbiór wyników głosowania w PRL nie oznaczał naturalnie aprobaty Kremla dla tego typu „eksperymentów”, jakie w jego rozumieniu zagrażały stabilności komunistycznego porządku ustrojowego, choćby z uwagi na aktywność antysystemowych sił społecznych. Jeszcze przy okazji następnych wyborów do sejmu w 1961 r. niektórzy członkowie kierownictwa KPZR - wspominając m.in. stanowisko i zaangażowanie Kościoła katolickiego podczas kampanii wyborczej w styczniu 1957 r. - ironizowali, czy aby na pewno tym razem „Polska poradzi sobie bez poparcia Wyszyńskiego?”, którego ten udzielił rządowi cztery lata wcześniej ${ }^{17}$.

Stosunek innych krajów bloku wschodniego do wyborów wynikał z krytycznego stanowiska, jakie generalnie zajmowały one wobec polskich przemian w 1956 roku. Zdecydowanie najbardziej nieprzychylni PRL byli wówczas przywódcy Niemieckiej

13 Za: ibidem, s. 374-375.

14 [po 12 stycznia], notatka ze spotkania ambasadora ZSRR z władzami Stowarzyszenia Dziennikarzy Polskich i przedstawicielami prasy warszawskiej, [w:] Polskie Dokumenty Dyplomatyczne 1957, red. K. Ruchniweicz, T. Szumowski, Warszawa 2006, s. 21.

15 Z Raportu Ambasadora PRL w Moskwie Tadeusza Gedego..., s. 126.

16 Prasa światowa o wyborach do Sejmu PRL, „Trybuna Ludu” 1957, nr 22, s. 2.

17 AMSZ, z. 3/65, w. 22, Skrót raportu politycznego Ambasady w Moskwie za okres od 1. I. 1961 r. do 30 VI 1961 r., b. p. 
Republiki Demokratycznej, Czechosłowacji oraz Albanii, którzy w obawie przed groźbą utraty władzy nie dokonali w swoich krajach, nawet ograniczonych, reform destalinizacyjnych. Doprowadziło to do wyraźnego ochłodzenia czy wręcz kryzysu w stosunkach Warszawy z Berlinem Wschodnim, Pragą i Tiraną. Grupy rządzące tych państw, niejako w samoobronie przed rozprzestrzenianiem się „polskiej zarazy”, rozpoczęly w 1956 r. szeroką kampanię propagandową przeciwko PRL i polityce nowego kierownictwa PZPR, używając argumentów o kontrrewolucji i rewizjonizmie, ograniczając jednocześnie kontakty z Polską nie tylko na płaszczyźnie partyjno-państwowej, ale również w takich dziedzinach, jak kultura, nauka czy nawet gospodarka ${ }^{18}$.

W NRD kulminacja niepokoju sytuacją u wschodniego sąsiada nastąpiła w październiku 1956 r. w związku z przebiegiem VIII plenum KC PZPR i objęciem przywództwa w partii przez Gomułkę. Przywódca Niemieckiej Socjalistycznej Partii Jedności (NSPJ) Walter Ulbricht oświadczał na jednym z plenów partyjnych, że „pewne eksperymenty przeprowadzone w Polsce stanowiły odrzucenie leninowskiej teorii państwa, zaprzeczenie kierowniczej roli partii, sojuszu robotniczo-chłopskiego oraz przyjaźni ze Związkiem Radzieckim”. Wypowiadając się przeciwko upublicznianiu referatu Chruszczowa na temat kultu Stalina, Ulbricht dowodził, że uchwały XX Zjazdu KPZR zostały wykorzystane w niektórych krajach „demokracji ludowej” przez „elementy szowinistyczne i nacjonalistyczne” do ugruntowania własnych dróg do socjalizmu, a powstała w ten sposób teoria „narodowego komunizmu” oznacza nic innego, jak „poddanie się wplywom ideologii burżuazyjnej"19.

$\mathrm{W}$ podobnej tonacji odnoszono się również do polskich wyborów. Władze NRD wysłały też do PRL specjalną delegację, która obserwowała kampanię wyborczą i na bieżąco raportowała o jej przebiegu. Członkowie delegacji rozmawiali z przedstawicielami aparatu partyjnego i administracyjnego oraz uczestniczyli w niektórych zebraniach wyborczych. Na jednym z takich spotkań enerdowcom zadawano kłopotliwe pytania dotyczące np. nieopublikowania u nich przemówienia Gomułki z VIII Plenum czy też powodów niewpuszczania obywateli PRL do NRD. Niemcy odpowiadali, że działania ich władz spowodowało zachowanie w NRD polskich dziennikarzy, którzy w rozmowach mieli krytykować politykę NSPJ i nawoływać do dymisji Waltera Ulbrichta ${ }^{20}$.

18 Por.: M. Paździora, Międzynarodowy ruch komunistyczny wobec polskiego października 1956, [w:] Przełomowy rok 1956. Poznański Czerwiec Polski Październik. Budapeszt. Materiały międzynarodowej konferencji naukowej. Poznań, 26-27 czerwca 1996 r., red. E. Makowski i S. Jankowiak, Poznań 1998, s. 164-165.

19 Za: M. Paździora, op. cit., s. 165; zob.: E. Labor, Der Rapacki - Plan und die DDR. Die Entspannungsvision des polnischen Außenministers Adam Rapacki und die deutschlandpolitischen Ambitionen der SED-Führung in den fünfziger und sechziger Jahren, Berlin 2003, s. 50 nn.; AMSZ, z. 10, w. 48, t. 463, Notatka informacyjna o sprawach wynikających ze stosunków między Polska a Niemiecka Republika Demokratyczną. Stosunek NRD do Polski w okresie między VIII i IX Plenum KC PZPR, k. 17-18; Archiwum Akt Nowych (dalej: AAN), KC PZPR, sygn. XIA/45, Uzupetnienie notatki z dnia 29. 11. $1956 r$. w sprawie aktualnych wydarzeń w stosunkach między Polska a NRD, k. 94.

20 Sprawozdanie delegacji $z$ NRD obserwujacej wybory do Sejmu PRL $z$ wizyty w zakładzie produkującym rowery, styczeń 1957, [w:] Polska - Niemcy Wschodnie 1945-1990. Wybór dokumentów, red. 
W kampanii wyborczej, zdaniem strony enerdowskiej, dało się zauważyć zupełne negowanie dotychczasowych osiągnięć Polski jako państwa socjalistycznego. Dyskutowano przede wszystkim - jak zauważali wysłannicy z NRD - o błędach przeszłości, a w partii zaznaczał się głęboki podział na stalinowców i nie stalinowców. Podkreślano, że wokół Gomułki rozwinął się kult jednostki, ci zaś członkowie partii, którzy nie podzielali poglądów nowego I sekretarza, byli wydalani z szeregów PZPR ${ }^{21}$.

Oprócz tego enerdowcy wyrażali zdziwienie i zaniepokojenie antysemityzmem obecnym w trakcie kampanii do sejmu. Odnosili się jednocześnie z rezerwą do wyjaśnień Gomułki w tej sprawie, który miał stwierdzić, że nosicielami tegoż antysemityzmu są konserwatywne siły w partii (zdaniem przedstawicieli NRD, był to dodatkowy element presji na stare kadry partyjne). Wielu członków PZPR pochodzenia żydowskiego na szczeblu lokalnym - twierdzili Niemcy - wręcz prześladowano, a partia ich nie wspierała, gdyż w samych jej szeregach narastały coraz bardziej tendencje antysemickie. Nagonka na osoby pochodzenia żydowskiego - jak zauważano - doprowadziła do emigracji z Polski wielu młodych ludzi ${ }^{22}$.

Oczywiście członkowie delegacji NRD dostrzegali powszechne wówczas nastroje antyradzieckie w PRL. Dowodzili w swoim raporcie, że nawet przedstawiciele aparatu PZPR oczerniają kierownictwo partii radzieckiej; rozpowszechniane są także niewybredne dowcipy o Chruszczowie. Zgorszenie enerdowców wywoływał szczególnie fakt, iż w trakcie zebrań wyborczych funkcjonariusze partii nie przeciwdziałali wystąpieniom skierowanym przeciwko ZSRR. Wśród inteligencji szerzyły się natomiast sympatie prozachodnie, które rozpowszechniały się także wśród innych grup społecznych. Potwierdzeniem takiego stanu rzeczy - według wysłanników z NRD - miały być przypadki wypowiedzi niektórych członków aparatu partyjnego, utrzymujących, że obecnie Polska jest suwerenna dzięki pomocy zachodnich pożyczek, zwłaszcza amerykańskich, które doprowadzą do wzrostu stopy życiowej ${ }^{23}$.

Po ogłoszeniu wyników wyborów delegaci z NRD przyznawali, że stanowią one duży sukces Gomułki. W prasie pojawiła się np. wypowiedź Johannesa Dieckmanna, przewodniczącego Izby Ludowej NRD: „Wynik wyborów do Sejmu polskiego oznacza triumf demokracji socjalistycznej $w$ sasiadującym $z$ nami ludowo-demokratycznym kraju (...). Z własnej woli cały prawie naród polski podążył do urn wyborczych, $z$ własnej woli opowiedział się za dalszym prowadzeniem socjalistycznego budownictwa pod przewodnictwem Polskiej Zjednoczonej Partii Robotniczej (...). W ten sposób naród polski udaremnit spekulacje państw zachodnich, które liczyly na to, że Polska oderwie się od obozu pokoju i socjalizmu (...)"24.

J. Kochanowskiego i K. Zemera, t. 3, lata 1956-1957, Warszawa 2008, s. 301.

21 /Bericht/ der Delegation über die Erfahrungen beim Studium der Wahlen in der Volksrepublik Polen (Arbeitsgruppe Stettin), [w:] ibidem, s. 302.

22 Ibidem, s. 303.

23 Ibidem, s. 304.

24 Światowe echa wyborów w Polsce, „Trybuna Ludu” 1957, nr 23, s. 2. 
Rzeczywisty pogląd strony enerdowskiej wyrażały jednakże wnioski zawarte w raporcie wspomnianej delegacji obserwatorów. Stwierdzano tutaj, że przywódca polskiej partii zawdzięczał swój kapitał polityczny i powodzenie przy urnach przede wszystkim nastrojom nacjonalistycznym, jakie miały panować $\mathrm{w}$ polskim społeczeństwie. W kręgach reakcyjnych („reaktionären Kreise”) był bowiem postrzegany jako bohater walki o suwerenność Polski przeciwko Związkowi Radzieckiemu. $\mathrm{W}$ ten sposób, co jeszcze raz podkreślano, rozwinął się znacznie kult jednostki („Personenkult”) wokół I sekretarza, spotęgowany poparciem, jakim cieszył się wśród zdecydowanej większości aparatu partyjnego ${ }^{25}$.

Wysłannicy NSPJ wyrażali jednocześnie przekonanie, że wyłoniony Sejm przysporzy władzom PRL szeregu kłopotów politycznych, co uwidoczni się po sformowaniu nowego rządu i podjęciu pracy przez parlament. Sugerowano, że wejście do Sejmu niektórych osób (wymieniano tutaj z nazwiska Eligiusza Lasotę) wzmocni tendencje anarchistyczne i brak dyscypliny w pracy parlamentu ${ }^{26}$.

Negatywny kontekst polskich wyborów uwypuklano w NRD jeszcze wiosną 1957 r., kiedy przygotowywano własne wybory do terenowych przedstawicielstw ludowych. W trakcie odpraw dla aktywu prasowo-kulturalnego w Komitecie Centralnym NSPJ podkreślano, że w propagandzie wyborczej należy odwoływać się wyłącznie do praktyk radzieckich przy jednoczesnej krytyce rzekomo antyludowego charakteru zachodnioniemieckiego Bundestagu. Zakazywano jednocześnie wspominania o niedawnych polskich doświadczeniach wyborczych, które - jak dowodzono - nie byłyby przydatne w NRD. Podczas tej samej odprawy stwierdzono też prawdopodobnie, że PZPR zawdzięcza sukces w wyborach wyłącznie hasłom antyradzieckim oraz pomocy Kościoła katolickiego ${ }^{27}$.

Narastanie fermentu politycznego i społecznego w Polsce jesienią 1956 r. wywoływało olbrzymie zaniepokojenie władz Czechosłowacji. Za wszelką cenę dążono do wyciszenia wszelkich informacji o przemianach w PRL, oraz odwrócenia uwagi własnego społeczeństwa od sytuacji u północnego sąsiada. Usiłowano również zdyskredytować w oczach Czechów i Słowaków procesy zachodzące w Polsce argumentując, iż wynikły one ze słabości PZPR, która pozwoliła „podnieść głowę wrogim socjalizmowi żywiołom" oraz zaczęła sprzyjać coraz silniejszym tendencjom do restauracji kapitalizmu ${ }^{28}$.

Dopiero zakończenie VIII Plenum, rozładowanie napięcia na linii Warszawa-Moskwa oraz ogłoszenie przez ZSRR Deklaracji z 30 października wpłynęły na częściowe uspokojenie władz CSR ${ }^{29}$. Uwagę Pragi absorbowały wtedy już bardziej o wiele groźniejsze

25 /Bericht/ der Delegation über die Erfahrungen beim Studium der Wahlen in der Volksrepublik Polen (Arbeitsgruppe Stettin)..., s. 305.

26 Ibidem.

27 Za: K. Ruchniewicz, Warszawa - Berlin - Bonn. Stosunki polityczne 1949-1958, Wrocław 2003, s. 199.

28 AAN, KC PZPR, sygn. XI A/32, Raport polityczny Ambasady PRL w Pradze za okres sierpień 1956 - luty 1957, k. 143; AMSZ, z. 23, w. 8, t. 71, Notatka z rozmowy Pudysz - Cerny, k. 26.

2930 października 1956 r. rząd ZSRR wydał deklarację „O podstawach rozwoju i dalszego umacniania wspótpracy między ZSRR a innymi państwami socjalistycznymi”. W dokumencie Kreml zobo- 
wydarzenia na Węgrzech. Oficjalne stanowisko Komunistycznej Partii Czechosłowacji $(\mathrm{KPCz})$ wobec przemian październikowych zostało wyrażone w referacie Antonina Novotnego na posiedzeniu plenarnym w grudniu 1956 roku. Czechosłowacki przywódca nie użył wprawdzie argumentu o kontrrewolucji w odniesieniu do wydarzeń w PRL, jak robił to już wcześniej, ale stwierdził, że złożoną sytuację u północnego sąsiada wykorzystały siły reakcyjne, posługujące się hasłami nacjonalistycznymi i antyradzieckimi ${ }^{30}$.

Podczas kampanii wyborczej do sejmu, jak czytamy w raporcie ambasady PRL w Pradze, „prasa czechosłowacka była daleka od optymizmu $i$ wykazywała bardzo wiele wstrzemięźliwości w ocenie sytuacji w Polsce. Charakterystycznym momentem dla wszystkich artykułów było mocne akcentowanie poważnego niebezpieczeństwa, jakie stwarza duża aktywność sit reakcji popieranej przez wroga propagandę zachodniq̨. Poświęcając wiele miejsca trudnościom gospodarczym Polski, niemal wszystkie artykuly przemilczaly program Frontu Jedności i nakreślone w nim kierunki likwidacji błędów przeszłości (...)"31.

Zupełnie inna nuta towarzyszyła artykułom prasowym w Czechosłowacji po ogłoszeniu wyników wyborów. W cytowanym wyżej raporcie tym razem wyrażano „pełne uznanie dla rozwagi i dojrzałości politycznej naszego narodu oraz głęboki szacunek dla partii, która w tak trudnej sytuacji zdecydowała się na wybory idac do mas ze słowami prawdy i jasnym programem dalszego budownictwa socjalizmu" ${ }^{2}$.

Mimo tego w późniejszym czasie przywódcy KPCz niejednokrotnie prezentowali swoje wątpliwości co do słuszności zmian, które nastąpiły w PRL po październiku 1956 roku. Oprócz krytyki polityki rolnej PZPR (odwrót od kolektywizacji) i „pobłażania rewizjonistom" polską partię oskarżano o niewłaściwy stosunek do ZSRR, brak stanowczości w walce z wpływami Kościoła katolickiego oraz „tolerowanie niepokojących zjawisk $w \dot{z} y$ ciu kulturalnym". Pragę raziła ponadto zbytnia swoboda prasy w Polsce, która - jej zdaniem - miała być trybuną dla poglądów rewizjonistycznych (powoływano się w tym kontekście najczęściej na publikacje w tygodniku „Po prostu”) ${ }^{33}$.

wiązywał się do równoprawnego traktowania innych państw socjalistycznych i nieingerowania w ich sprawy wewnętrzne. Ogłoszenie deklaracji stanowiło jednocześnie pośrednie przyznanie się Moskwy do faktu, iż w okresie wcześniejszym jej stosunki z innymi krajami „demokracji ludowej” były dalekie od partnerskich (R. Łoś, Polska-ZSRR 1956, Łódź 1999, s. 83-84; K. Persak, Kryzys stosunków polsko - radzieckich w 1956 r., [w:] Polska 1944/45-1989. Polska 1956 - próba nowego spojrzenia, Studia i Materiaty, t. III, Warszawa 1997, s. 40).

30 M. Paździora, op. cit., s. 166; AMSZ, z. 7, w. 2, t. 14, Notatka ze spotkania w Ambasadzie Czeskiej dnia 6. 12. 1957, k. 52; ibidem, z. 7, w. 42, t. 411, Notatka $z$ rozmowy $z$ tow. Z. Cernym, Sekretarzem Ambasady CSR, k. 49-50.

31 AAN, KC PZPR, sygn. XI A/32, Raport polityczny Ambasady PRL w Pradze za okres sierpień 1956..., k. 149; zob. też: A. Szczepańska, Warszawa-Praga 1948-1968. Od nakazanej przyjaźni do kryzysu, Szczecin 2011, s. 249.

32 AAN, KC PZPR, sygn. XI A/32, Raport polityczny Ambasady PRL w Pradze za okres sierpień $1956 \ldots$, k. 149.

33 AMSZ, z. 7, w. 2, t. 14, Notatka ze spotkania w Ambasadzie Czechosłowackiej dnia 6. 12. 1957 r., k. 51-53. 
W Albanii w okresie wydarzeń październikowych początkowo unikano informowania o sytuacji w $\mathrm{PRL}^{34}$. Szybko jednak polskie przemiany zaczęto przedstawiać własnej opinii publicznej jako odwrót od socjalizmu, zerwanie przyjaźni ze Związkiem Radzieckim (czego dowodem miało być m.in. usunięcie marszałka Konstantego Rokossowskiego) oraz wkroczenie na rewizjonistyczną drogę jugosłowiańską. W tym samym stylu wyrażano się o świeżo wyłonionym kierownictwie polskiej partii. Przywódca Albańskiej Partii Pracy (APP) Enver Hodża, zapoznawszy się z referatem Gomułki z VIII Plenum, miał powiedzieć, że język, jakiego używał I sekretarz KC PZPR, jest językiem „reakcyjnego radia”, a on sam to „niepewny element, który był więziony za działalność antypaństwowa" 35 . Z kolei albański premier Mehmet Shehu nazwał Gomułkę „,bucharinowcem, likwidatorem”, a Biuro Polityczne PZPR powołane w październiku 1956 r. - „tworem bezprawnie skleconym”36.

Treści wystąpień przywódców albańskich zmieniły się nieco na początku 1957 roku. Zdecydowało o tym przede wszystkim podpisanie polsko-radzieckiego porozumienia w listopadzie $1956 \mathrm{r}^{37}$ oraz wyniki wizyty w PRL premiera Chińskiej Republiki Ludowej (ChRL) Zhou Enlaia (o czym będzie jeszcze mowa). Liderzy APP $\mathrm{w}$ rozmowach $\mathrm{z}$ polskimi dyplomatami w Tiranie zaczęli wyrażać się wówczas pochlebniej o umiejętnej - w ich rozumieniu - polityce Gomułki, dzięki czemu Polska uniknęła scenariusza węgierskiego ${ }^{38}$.

W takim kontekście nie mogło dziwić, że Albania przyjęła pozytywnie rezultaty polskich wyborów. Tuż po głosowaniu, wiceminister spraw zagranicznych Vasil Nathanaili w rozmowie z ambasadorem PRL w Tiranie Stefanem Przeniosło powiedział: „(...) nie miałem żadnej wątpliwości, iż zwycięstwo odniosą kandydaci Frontu Jedności Narodu, nie przypuszczałem jednak, że tak wysoki procent wyborców weźmie udział w głosowaniu. Ponad 99 procent otrzymanych głosów przez Władysława Gomulkę jest prawdziwym zwycięstwem (...)". Gratulując polskiemu kierownictwu partyjnemu i wyborcom, Nathanaili dodawał, że „Wasze zwycięstwo jest naszym zwycięstwem, zwycięstwem obozu socjalistycznego nad siłami, które chciałyby przywrócić rzady burżuazyjne"39.

Do wyborczego sukcesu PZPR odniósł się na plenum partyjnym także sam Enwer Hodża. Przywódca APP rozpoczął swoje wystąpienie od krytyki sytuacji w PRL, gdzie po XX Zjeździe KPZR „elementy reakcyjne rozpoczęly ofensywę przeciwko Związkowi Radzieckiemu i PZPR (...) Na łamach prasy polskiej ukazały się artykuły

34 AMSZ, z. 7/77, w. 52, t. 673, Depesze. Szyfrogram nr 17354 z Tirany nadany 23. 10.56 r., k. 7; ibidem, Depesze. Szyfrogram nr 17485 z Tirany nadany 25. 10.56 r., k. 8.

35 Za: W. J. Dziak, Albania między Belgradem, Moskwa i Pekinem, Warszawa 1991, s. 75; zob. też: AMSZ, z. 7/77, w. 52, t. 673, Depesze. Szyfrogram nr 18093 z Tirany nadany 5. 11.56 r., k. 10-11; Ibidem, Depesze. Szyfrogram $n r 18262$ z Tirany nadany 8. 11.56 r., k. 12.

36 AAN, KC PZPR, sygn. XIA/22, Wyciag z raportu politycznego Ambasady PRL $w$ Tiranie za okres od 15 VIII 1956 - 15 I 1957, k. 82.

37 Chodzi o wspólną deklarację podpisaną 18 listopada 1956 r. w Moskwie (zob.: A. Skrzypek, Mechanizmy uzależienia Stosunki polsko-radzieckie 1944-1957, Pułtusk 2002, s. 445).

38 AMSZ, z. 7/77, w. 56, t. 757, Depesze. Szyfrogram nr 791 z Tirany, nadany 21. 1. 57, k. 1.

39 Za: AMSZ, z. 7/77, w. 56, t. 757, Depesze. Szyfrogram nr 830 z Tirany, nadany 22. 1. 57, k. 1. 
wrogie Związkowi Radzieckiemu, co stworzyło dogodne warunki dla rozpowszechniania się reakcyjnej ideologii. Elementy prawicowe wyolbrzymiały popetnione błędy, przekreślając jednocześnie wszelkie osiagnięcia władzy ludowej $w$ minionym okresie (...)”. Wybory jednak - zdaniem Hodży - miały dowieść, że „Klasa robotnicza pod przewodem PZPR i towarzysza Gomulki pokrzyżowały plany reakcji (... ${ }^{40}$.

Uznanie dla wyników wyborów w PRL, podobnie jak w NRD i Czechosłowacji, nie zwiastowało w żadnym razie akceptacji Tirany dla nowej rzeczywistości politycznej w Polsce po 1956 roku. Władzom w Warszawie zarzucano później niezmiennie m.in. „pomniejszanie znaczenia i roli ZSRR na arenie międzynarodowej”, rewizjonistyczne podejście do zagadnień kultury oraz celową likwidację spółdzielni produkcyjnych i „popieranie kułaków na wsi”. Władze APP sugerowały również przy wielu okazjach Moskwie, aby „ukróciła polska anarchię” i powstrzymała „pokojowa kontrrewolucję", którą widziano w popaździernikowej polityce wewnętrznej PRL ${ }^{41}$.

Kierownictwa partyjne pozostałych państw radzieckiej strefy dominacji - Węgier, Bułgarii i Rumunii - również zareagowały negatywnie na przemiany październikowe w Polsce. Nie doprowadziło to wprawdzie, jak w przypadku NRD, Czechosłowacji czy Albanii, do drastycznego ochłodzenia w stosunkach z Warszawą, jednak można było zaobserwować ze strony przywódców wymienionych krajów wyraźny dystans zarówno do ekipy Gomułki, jak i korekt systemowych wprowadzonych przez nią w Polsce. Na kampanię wyborczą i wybory w PRL patrzono więc z dużymi obawami jako na dalszy ciąg „polskich eksperymentów” i kolejne zagrożenie dla obowiązującego systemu władzy.

Szczególna w tych okolicznościach była sytuacja Węgier, które, obok Polski, stały się drugim państwem bloku wschodniego, gdzie doszło do poważnego kryzysu rządów komunistycznych. Powstanie, jakie miało miejsce w tym kraju, wybuchło także pod wpływem wieści o zmianach październikowych w PRL. Brutalna sowiecka interwencja i pacyfikacja Węgier wyniosła do władzy Janosa Kadara. Władysław Gomułka, choć ostatecznie poparł działania ZSRR, miał poważne zastrzeżenia w kwestii militarnej formy rozwiązania przez Kreml „kryzysu węgierskiego”, a także okoliczności objęcia rządów przez ekipę Kadara. Wątpliwości polskiego przywódcy budziła także skala zastosowanych na Węgrzech represji w stosunku do biorących udział w powstaniu 1956 roku. Wszystko to powodowało znaczną rezerwę ze strony PRL wobec nowego kierownictwa w Budapeszcie ${ }^{42}$.

Tymczasem Kadar i władze węgierskie liczyły, że polepszenie stosunków z PRL wpłynie pozytywnie na ich wizerunek w oczach własnego społeczeństwa, w którym Gomułka, ze względu na jego odmienną od reszty przywódców bloku wschodniego postawę wobec kryzysu węgierskiego, cieszył się dużym autorytetem i popularnością. Jednak Budapeszt zamierzał intensyfikować kontakty z Warszawą wyłącznie na

40 AMSZ, z. 7/77, w. 56, t. 757, Depesze. Szyfrogram nr 1947 z Tirany, nadany 17. 2. 57, k. 7.

41 Cyt. za: W. J. Dziak, op. cit., s. 75-76.

42 J. Tischler, I do szabli... Polska $i$ Wegry. Punkty zwrotne $w$ dziejach obu narodów w latach 1956 oraz 1980-1981, Warszawa 2001, s. 123 i nn. 
obszarze relacji między kierownictwami partii, no i nie przed wyborami do sejmu, gdy jeszcze nie było wiadomo, jak rozwinie się sytuacja polityczna w PRL. Obawiano się negatywnego oddziaływania polskiego przykładu na ledwo co spacyfikowany po rewolucji kraj. Zresztą wielu konserwatywnych działaczy Węgierskiej Socjalistycznej Partii Robotniczej - WSPR (utworzonej w miejsce Węgierskiej Partii Pracujących) nie unikało otwartej krytyki „popaździernikowej” rzeczywistości w PRL, wskazując i uwypuklając przy różnych okazjach ideologiczne i psychologiczne oddziaływanie „wypadków” w Poznaniu oraz VIII Plenum KC PZPR na zaostrzenie sytuacji politycznej w ich kraju na jesieni $1956 \mathrm{roku}^{43}$.

Trudno się więc dziwić, że do gorącej i nieobliczalnej kampanii wyborczej w Polsce podchodzono na Węgrzech z nieukrywaną rezerwą. Charakterystyczna była w tych okolicznościach wypowiedź Lajosa Fehera, członka tymczasowego KC WSPR, który $\mathrm{w}$ rozmowie $\mathrm{z}$ polskim dyplomatą stwierdził, że Węgry patrzą na rozwój sytuacji w Polsce $\mathrm{z}$,wielkim niepokojem i troska” (...). Nowe kierownictwo PZPR doprowadziło demokratyzacje życia $w$ Polsce do ostatecznych granic tak, że wykroczenie poza nie - biorąc pod uwage warunki tego kraju - oznaczałoby zrezygnowanie $z$ demokracji socjalistycznej i otwarcie drogi dla demokracji burżuazyjnej". Odnosząc się do ordynacji wyborczej Feher przewidywał, że nie gwarantuje ona przejścia kandydatów komunistycznych, a „stosunek ilościowy tych kandydatów do reszty jest zbyt mały”. Wyrażał jednak nadzieję, że „zwycięstwo wyborcze PZPR i pomyślny przebieg naszych wyborów stanowilyby dla partii i rządu węgierskiego ogromna pomoc" ${ }^{44}$.

Inny prominentny przedstawiciel WSPR, György Csatár (redaktor naczelny gazety „Nèpszabadság” - organu prasowego WSPR), obawiał się, że podczas kampanii wyborczej w Polsce dojdzie do „dalszego wzrostu fali nacjonalizmu i antysemityzmu, które moga doprowadzić do rozlewu krwi, zamieszek itd.". Co ciekawe, w odróżnieniu od wyżej cytowanego Lajosa Fehera, stwierdzał, że „System wyborczy podoba się nam i mamy zamiar wzorować się na nim". Dodawał jednakże, że na Węgrzech, w związku z niedawnymi wydarzeniami, o zorganizowaniu wyborów będzie można pomyśleć nie wcześniej, jak za rok lub półtora ${ }^{45}$.

W przededniu głosowania w Polsce Janosz Kadar oświadczył, że „najżywszy okres kampanii wyborczej wskazuje na konsolidację narodu polskiego wokót partii, chociaż wciąż z troską oczekuje wyników jutrzejszych wyborów ważnych nie tylko dla Polski, ale i dla Wegier oraz dla całego obozu socjalizmu". Przywódca węgierski skrytykował jednocześnie polską prasę, zauważając dosadnie, iż „włosy mi jednak stają na głowie, kiedy czytam tłumaczenia niektórych artykułów waszej prasy, zwłaszcza z czasopism kulturalnych" 46 .

43 AMSZ, z. 7, w. 68, t. 558, Raport Ambasady PRL w Budapeszcie za okres - II pótrocze 1957 r., k. 57; J. Tischler, I do szabli..., s. 111 i nn.; idem, Polski październik a Węgry, [w:] Polski Październik 1956 w polityce światowej, red. J. Rowiński, Warszawa 2006, s. 113.

44 AMSZ, z. 7, w. 62, t. 527, Notatka J. Moszczeńskiego z rozmowy z L. Feherem, członkiem tymcz. KC WSPR $z$ dnia 9. I. 1957 r., k. 162-163.

45 AMSZ, z. 7, w. 62, t. 527, Notatka. Budapeszt, dnia 11. I. 57 r. J. Moszczeński, k. 164.

46 Szyfrogram Nr 925 z Budapesztu, nadany 23. 1.57, 9.oo, [w:] Polskie Dokumenty Dyplomatyczne..., s. 75 . 
Pozytywne dla Warszawy, a w Budapeszcie przyjęte z zadowoleniem i ulgą, wyniki głosowania spowodowały, że liderzy WSPR zaczęli manifestować przed własnym społeczeństwem chęć zbliżenia z Polską. Jednocześnie w dalszym ciągu władze węgierskie obawiały się „niebezpiecznych wpływów” z PRL, wypominając jeszcze długo polskiemu kierownictwu „nieszczere zwalczanie rewizjonizmu $w$ szeregach partii”, tolerowanie „szkodliwych prądów w kulturze” czy też jedyne w „obozie socjalistycznym zapóźnienia" w dziele uspółdzielczenia wsi ${ }^{47}$.

W Bułgarii, na czele z kierownictwem Bułgarskiej Partii Komunistycznej (BPK), śledzono $\mathrm{z}$ dużym napięciem kampanię wyborczą w PRL. Obawy Sofii wynikały oczywiście z jej krytycznego stosunku do całokształtu wydarzeń w PRL w 1956 r., które postrzegano jako zagrożenie dla socjalizmu oraz dążenie do uniezależnienia się od Związku Radzieckiego. Wypada jednak zauważyć, że dezaprobata ze strony Bułgarii dla polskich przemian październikowych wyrażana była w dość „subtelny” sposób poprzez zastępczą krytykę „wynaturzeń socjalizmu”, jakie miały miejsce w Jugosławii ${ }^{48}$.

Na temat wyborów w Polsce wypowiedział się na spotkaniu z ambasadorem PRL w Sofii, Leonem Szygułą, przewodniczący bułgarskiego Prezydium Zgromadzenia Narodowego Georgi Damjanow. Stwierdził on m.in., , że początkowo kierownictwo tutejsze miało poważne wątpliwości, ale ostatnie posunięcia partii i rządu [PRL R.S.], a przede wszystkim rezultaty wyborów, sq dla nich dowodem, że Polska idzie po stusznej linii, że polska klasa robotnicza ma tak piękne, bojowe tradycje, i że tutejsze kierownictwo bardzo jest rade $z$ wyników wyborów" 49 .

Warto dodać, że pomimo oficjalnie wyrażanego zadowolenia z wyników głosowania do sejmu PRL, kierownictwo BPK nie stroniło w dalszym ciągu od krytycznych ocen procesów zachodzących w Polsce, zwłaszcza koncepcji tzw. „własnej drogi do socjalizmu", której elementem - według Sofii - był przebieg kampanii wyborczej i samych wyborów. Bułgarskie zarzuty wobec PRL były jednak echem minionej już epoki, czego próbką mogą być sformułowania $\mathrm{w}$ jednym $\mathrm{z}$ artykułów prasowych, gdzie, obok oskarżeń o „podważanie prawdziwych zasad marksizmu” czy „dyskredytowania radzieckiego sytemu socjalistycznego", pojawiła się nawet pretensja o potępianie Józefa Stalina, będącego w opinii BPK niezmiennie „wielkim marksistą, który ofiarnie walczył o wprowadzenie w życie idei leninowskich” oraz „bronił leninizmu przeciwko zakusom rewizjonistów i oportunistów" (! $)^{50}$.

Przywódcy Rumunii odbierali przemiany 1956 r. w PRL podobnie jak kierownictwa wymienionych już wcześniej krajów. Wskazywano więc na przejawy „polskiego rewizjonizmu", zarzucano nowym władzom PZPR niewłaściwą politykę rolną, nadmierną swobodę Kościoła katolickiego oraz „nie dość pryncypialne podejście do prob-

47 AMSZ, z. 7, w. 68, t. 559, Raport Ambasady PRL w Budapeszcie za okres od 1. IV do 31. XII. 1958 r., k. 52; J. Tischler, Polski październik a Wegry..., s. 113.

48 AMSZ, z. 7, w. 31, t. 307, Raport Ambasady PRL w Sofii za okres 1. IV. - 31. XII. 1956 r., k. 12.

49 Szyfrogram Nr 1102 z Sofii, nadany 27. I. g. 22.oo, [w:] Polskie Dokumenty Dyplomatyczne..., s. 77.

50 AMSZ, z. 7, w. 32, t. 330, G. Bokow, Czy komunizm narodowy? Tłumaczenie z „Rabotniczeskowo Deła" - 25. III. 1957 r., k. 12-14. 
lemów rozwoju kultury". Podkreślić przy tym należy, że krytyka ze strony Rumunów wykazywała znaczny umiar i nie przybierała postaci otwartych oskarżeń czy propagandowej nagonki, jak miało to miejsce w przypadku NRD czy Czechosłowacji ${ }^{51}$.

Tym niemniej Bukareszt podjął na przełomie lat 1956 i 1957 szereg środków „przeciwko przenikaniu wpływów z Polski”. Społeczeństwo rumuńskie nie było właściwie informowane o sytuacji i przemianach w PRL, a także o przebiegu kampanii wyborczej do sejmu. Przerwaniu uległ dopływ polskiej prasy, w 1957 r. zaś wstrzymano również coroczną wymianę dziennikarzy. Władze w Bukareszcie patrzyły niechętnie nawet na rozpowszechnianie biuletynu informacyjnego Ambasady PRL - zdarzały się wypadki wycofywania tego wydawnictwa $\mathrm{z}$ bibliotek publicznych i przeznaczania go jedynie do użytku wewnętrznego organizacji partyjnych ${ }^{52}$.

Obawy Rumunów co do kierunku rozwoju sytuacji w Polsce zostały w znacznym stopniu rozwiane po ogłoszeniu wyników polskiego głosowania. Charakterystyczna była w tej sytuacji wypowiedź jednego z rumuńskich wicepremierów, który w rozmowie z ambasadorem PRL Piotrem Izydorczykiem stwierdził: „stosunek Rumunii do Polski w tym okresie (tj. przed wyborami - R.S.) nigdy nie był niechętny, a najwyżej zajęto pozycję wyczekująca" ${ }^{\prime 3}$.

Odmiennie niż w bloku wschodnim na wydarzenia październikowe i wybory w PRL zareagowano w państwach komunistycznych spoza radzieckiej strefy dominacji - Chinach i Jugosławii. W przypadku tej ostatniej powrót do władzy Gomułki i postanowienia VIII Plenum KC PZPR przyjmowano z zadowoleniem i satysfakcją, ponieważ łącznie z wynikami XX zjazdu KPZR stanowiły one dla ekipy Josifa Broz-Tity potwierdzenie właściwego kierunku obranej w 1948 r. strategii politycznej. Nie mogło więc dziwić zbliżenie, do jakiego po Październiku doszło między Warszawą a Belgradem, a którego podstawą było zgodne stanowisko obydwu stron w odniesieniu do krytycznej oceny stosunków państw komunistycznych z ZSRR $\mathrm{w}$ czasie rządów Stalina oraz w sprawie idei odmiennych dróg do socjalizmu ${ }^{54}$.

Nadchodzące wybory sejmowe w Polsce traktowano w Jugosławii jako kolejny krok na drodze przemian zapoczątkowanych przez ekipę Gomułki i nie kryto poparcia dla ich idei oraz ówczesnej polityki kierownictwa PZPR. Stąd też w okresie kampanii wyborczej na początku stycznia 1957 r. sytuacja w PRL w dalszym ciągu absorbowała zarówno władze, jak i jugosłowiańską opinię publiczną. Strona polska z satysfakcją konstatowała, że „Podczas gdy prase innych krajów socjalistycznych,

51 AAN, KC PZPR, sygn. 237/V/382, Stosunki polsko-rumuńskie w latach 1958-1961, k. 27.

52 AMSZ, z. 7, w. 33, t. 335, Stosunki polsko-rumuńskie, k. 84; ibidem, z. 7, w. 33, t. 338, Notatka $z$ rozmowy $z$ V-ce ministrem Spraw Zagranicznych RRL Malnašan'em w dniu 24 lipca 1958 r., k. 59.

53 AAN, KC PZPR, sygn. XIA/58, Stosunki polsko-rumuńskie (skrót), k. 35-36.

54 Ożywieniem kontaktów z Związkiem Komunistów Jugosławii (ZKJ) Gomułka zamierzał nie tylko dodatkowo akcentować odrębności polskiego systemu ustrojowego, wprowadzone na jesieni 1956 r., ale także skorzystać z pozycji Belgradu na Zachodzie dla ewentualnego wsparcia swoich starań o międzynarodowe uznanie granicy na Odrze i Nysie Łużyckiej (M. Paździora, op. cit., s. 164; AAN, KC PZPR, sygn. 237/XXII/810, Wspólne oświadczenie o stosunkach między Związkiem Komunistów Jugosławii a Polska Zjednoczonq Partia Robotnicza, k. 45-47, 50 i nast.; AMSZ, z. 7, w. 20, t. 191, Jugosławia w okresie listopad 1956 - 10 kwiecień 1957. Stosunki polsko-jugosłowiańskie, k. 63-64). 
poza prasa chińską, cechowała wstrzemięźliwość i wyczekiwanie wobec "polskiego eksperymentu wyborczego", to prasa jugosłowiańska charakteryzowała styczniowe wybory w Polsce jako "nadzieje na jeszcze jeden triumf postępowych sit Polski”"55.

Odnosząc się do wyborów, jugosłowiańscy komuniści podkreślali, iż „klasa robotnicza i komuniści polscy mieli odwagę i siłę, by wkroczyć na bynajmniej niełatwa droge, by rozpocząć walkę na kilku frontach: przeciwko siłom stalinowskim, przeciwko próbom restauracji dawnego reżimu, podejmowanym przez reakcję burżuazyjno-klerykalna oraz o wprowadzenie w życie demokracji socjalistycznej"56. Oczywiście w wynikach głosowania kierownictwo jugosłowiańskie widziało zwycięstwo nowych władz partyjnych, zwłaszcza Gomułki i jego podejścia do budowy socjalizmu ${ }^{57}$.

Przywódcy ChRL pilnie analizowali rozwój politycznej odwilży w Polsce po XX Zjeździe KPZR. Wiele miejsca poświęcono wydarzeniom poznańskiego czerwca wprawdzie bunt robotniczy w PRL oceniono w Pekinie dość jednoznacznie jako spisek kontrrewolucyjny, ale po pewnym czasie starano się także dostrzegać jego rzeczywiste powody. Niezwykle ciepło we wrześniu 1956 r. przywitano w stolicy Chin Edwarda Ochaba, który na czele delegacji PZPR gościł na VIII Zjeździe Komunistycznej Partii Chin (KPCh). Władze ChRL w sposób widoczny deklarowały swoje poparcie dla przemian zachodzących w Polsce na jesieni 1956 roku $^{58}$. Jednak uwaga Chińczyków nie skupiała się na chęci zrozumienia wewnętrznych uwarunkowań polskich przemian, co na ich skutkach zewnętrznych, związanych z rozluźnieniem związków PRL z ZSRR. Aprobata Pekinu dla Października i Gomułki miała zatem ograniczony charakter, stanowiąc swego rodzaju pochodną stosunków chińsko-radzieckich (wkraczających w etap rywalizacji o prymat w światowym ruchu komunistycznym). Była również uzależniona od zdolności nowego kierownictwa PZPR do opanowania sytuacji politycznej w kraju i zachowania ciągłości systemu ustrojowego ${ }^{59}$.

W Pekinie śledzono zatem z pewnym niepokojem sytuację polityczną w Polsce i poczynania nowego kierownictwa PZPR. Na przełomie grudnia 1956 r. i stycznia 1957 r. obawy ChRL zaczęły budzić wybory do Sejmu. Zdaniem przywódców KPCh, przebieg kampanii wyborczej wskazywał, że w PRL dochodziły do głosu „elementy reakcyjne i nacjonalistyczne". Wskazywano również na wzmagającą się falę nastrojów antyradzieckich, a także antysemickich (Ambasada ChRL odnotowywała nasilenie wyjazdów z Polski osób pochodzenia żydowskiego). Ostrzegano z tego powodu

55 AAN, KC PZPR, sygn. XIA/42, Stosunki polityczne z Jugosławia, k. 25.

56 Ibidem.

57 AMSZ, z. 7, w. 23, t. 232, Polska na łamach prasy jugosłowiańskiej (Przegląd prasy za okres od 20. I. 57 do 10. IV. br. włącznie), k. 193.

58 AMSZ, z. 12, w. 5, t. 92, Raport polityczny Ambasady PRL w Pekinie $z$ dn. 5. VII. 57, k. 18; Shen Zhihua, Li Danhui, Kryzys w Polsce 1956 r. i stosunki polsko-chińskie widziane z Pekinu, [w:] Polski Październik 1956 w polityce światowej..., s. 76-79.

59 Szyfrogram nr 17599 z Pekinu nadany 27. 10, [w:] Chiny a polski Październik 1956, oprac. A. Werblan, „Dziś” 1996, nr 10, s. 125; AAN, KC PZPR, sygn. 237/XXII/780, Rozmowa Ambasadora Chińskiej Republiki Ludowej tow. Wang-Ping-nan-Czesak, dn. 13. X. 56 r., k. 40. 
Warszawę przed niebezpieczeństwem powszechnych skreśleń kandydatów PZPR, co mogło doprowadzić do "osłabienia więzi z krajami obozu socjalistycznego"60.

O tym, jak dużą wagę przywiązywano w Pekinie do polskich wyborów, świadczył przebieg wizyty w PRL premiera ChRL Zhou Enlaia. Notabene już sama data przyjazdu chińskiego gościa - 11-15 stycznia 1957 r. - odczytywana była jako wsparcie KPCh dla PZPR w przededniu głosowania, czego też nie ukrywali w swoich komentarzach chińscy politycy. Podczas rozmów oficjalnych Zhou Enlai wskazywał, że obecni na listach wyborczych partyjni kandydaci na posłów oraz ich sojusznicy mogą w toku wyborów okazać się niepewni i odżegnać od oficjalnej linii PZPR. Rodziło to niebezpieczeństwo, że partia będzie mniejszością w wyłonionym sejmie ze wszystkimi tego konsekwencjami. Zdaniem chińskiego premiera, PZPR powinna mieć przygotowaną strategię działań na wypadek, gdyby partia znalazła się w parlamencie w mniejszości ${ }^{61}$.

Gomułka z kolei uspokajał chińskiego gościa, twierdząc, że kierownictwo KPCh przecenia niebezpieczeństwo, jakie groziłoby ewentualnie PZPR w trakcie wyborów. Zdaniem polskiego przywódcy, wybory na pewno nie stworzą takiej sytuacji, która doprowadziłaby do utraty władzy przez partię. Jedyne obawy, jakie wyraził Gomułka, dotyczyły możliwej niskiej frekwencji, co mogło zrodzić konieczność powtórzenia głosowania w niektórych okręgach. Jednak i w takim wypadku - przekonywał - „łatwiej będzie przeprowadzić (...) tych kandydatów, których się chce. Moglyby powstać pewne trudności polityczne, gdyby niektórzy kandydaci nie zostali wybrani, ale to sa trudności do pokonania"62.

Zhou Enlaj zaangażował się także bezpośrednio w kampanię wyborczą, odwiedzając w trakcie swojego pobytu w Polsce, oczywiście poza Warszawą, także Kraków, Wrocław i Łódź, gdzie organizowano masowe spotkania z ich mieszkańcami. Właśnie na takim wiecu w Łodzi, w obecności Romana Zambrowskiego, chiński przywódca deklarowal, iż „naród chiński popiera Was w szlachetnej sprawie budowy socjalizmu. Chiny i Polska jako członkowie wielkiej rodziny socjalistycznej sa bliskimi braćmi. Na drodze obrony pokoju światowego i budowy socjalizmu naród chiński będzie zawsze kroczył ramię przy ramieniu $z$ narodem polskim"63. Z kolei Roman Zambrowski, dziękując premierowi ChRL za poparcie, apelował do zebranych o głosowanie na FJN oraz podkreślał „Zrozumienie, jakie rząd Chin i Komunistyczna Partia Chin Ludowych okazuja dla wewnętrznych spraw naszego kraju, przeżywajacego dziś doniosty przetom (...)" 64 .

60 AAN, KC PZPR, sygn. XIA/30, Notatka $z$ rozmowy $z$ radca ambasady ChRL $w$ Warszawie tow. Ju Czang, przeprowadzonej dnia 21. XII. 1957 r. z inicjatywy strony chińskiej, oraz z rozmowy $z$ Ambasadorem ChRL, k. 7; ibidem, KC PZPR, sygn. 237/XII/780, Notatka. Sprawy polskie w ChRL, Pekin, dn. 18. I. 1957 r., k. 70.

61 Notatka z przeprowadzonych rozmów w dniach 11 i 12. I. 1957 r. między delegacjami ChRL i Polski, [w:] Polskie Dokumenty Dyplomatyczne..., s. 47.

62 Ibidem, s. 48-49.

63 Z przemówień na wiecu w Łodzi. Czou En Lai: Naród chiński popiera Was w sprawie budowy socjalizmu, „Trybuna Ludu” 1957, nr 15.

64 Zambrowski: Zacieśnienie naszej wspótpracy przyniesie korzyść całemu obozowi socjalizmu, ibidem. 
Wyniki głosowania w Polsce przyjęto w Pekinie - jak czytamy w informacji dyplomatycznej - ze „szczera radością". Jeden z polityków chińskich, wiceminister spraw zagranicznych Czan Wen-tien, miał stwierdzić, że „rezultaty wyborów rozproszyly obawy co do dalszego rozwoju sytuacji w Polsce". Dodawał też - w duchu charakterystycznego komunistycznego dydaktyzmu - „że PZPR powinna wykorzystać zwycięstwo $w$ głosowaniu dla umocnienia swojej jedności oraz autorytetu w społeczeństwie". Inni przedstawiciele ChRL nie omieszkiwali wskazywać, że do sukcesu wyborczego ekipy Gomułki przyczyniła się poważnie wizyta w PRL ich premiera ${ }^{65}$.

W okresie późniejszym ChRL, podobnie jak i inne państwa socjalistyczne, odnosiła się negatywnie do wielu elementów „popaździernikowej” rzeczywistości w PRL. Władzom polskim zarzucano najczęściej nadmierną swobodę prasy, która - według Pekinu - stawała się niejednokrotnie „trybuną rewizjonistów”. Chińczycy byli zdania, że w licznych publikacjach w PRL, nawet w czasopismach partyjnych, zbyt dużo miejsca poświęca się omawianiu błędów i niedociągnięć poprzedniego okresu, pomijając jednocześnie sukcesy, będące - jak dowodzono - udziałem Polski przed 1956 r., a związane chociażby z uprzemysłowieniem. Zastrzeżenia Pekinu budziła również sytuacja w polskiej kulturze i odcięcie się środowisk twórczych w PRL od socrealizmu. Wymiana kulturalna między obydwoma krajami miała $z$ tego powodu bardzo ograniczony zakres, czego dość wymownym przykładem był zakaz wyświetlania w ChRL polskich filmów ${ }^{66}$.

Sytuacja w PRL w 1956 r., szczególnie wydarzenia październikowe, a później wybory, skupiały uwagę także po drugiej stronie żelaznej kurtyny. Według Stanów Zjednoczonych polityka nowego kierownictwa PZPR pod przywództwem Gomułki, mogła prowadzić do coraz większej niezależności Polski od Kremla. Elementem tego procesu były również wybory, choć strona amerykańska zdawała sobie naturalnie sprawę, że wyłanianie składu Sejmu PRL, zważywszy na uwarunkowania międzynarodowe i sytuację Polski, nie może odbyć się w sposób w pełni demokratyczny. Starano się jednak - „dla dobra sprawy” - nie wyrażać oficjalnie opinii na temat wolności wyborów ${ }^{67}$.

Taka strategia - zdaniem Jakuba Tyszkiewicza - znalazła swoje odbicie w określonych działaniach informacyjnych. Odczuła to choćby Rozgłośnia Polska Radia Wolna Europa (RWE). Departament Stanu zareagował na protest władz PRL z powodu nadawania audycji wzywających do skreślania z list wyborczych czternastu najbardziej skompromitowanych w okresie stalinowskim działaczy PZPR. RWE musiała

65 AMSZ, z. 12, w. 5, t. 93, Notatka, luty 1957 r., k. 4; ibidem, Notatka, styczeń 1957 r., k. 9.

66 AAN, KC PZPR, sygn. XIA/30, Wyciag z raportu politycznego Ambasady PRL w Pekinie za okres od 1. I. Do 30. VI. 1958 r., k. 394; AMSZ, z. 12, w. 4, t. 86, Notatka na temat referatu pomocnika Ministra Spraw Zagranicznych ChRL Chiao Kuan-hua, analizującego niektóre problemy z referatu Czou En-laia, k. 31.

67 J. Tyszkiewicz, Stany Zjednoczone wobec wyborów w Polsce 1947 - 1957 - 1989, [w:] Wybory i referenda $w$ PRL, red. M. Ligarski i M. Siedziako, Szczecin 2014, s. 768-769; M. Kula, Paryż, Londyn i Waszyngton patrza na Październik 1956 r. w Polsce, Warszawa 1992, s. 185; Notatka Departamentu Stanu na temat wyborów w Polsce, 17 stycznia 1956 r., [w:] Kampania wyborcza i wybory..., s. 305-306. 
się dostosować do amerykańskich wytycznych (uzgodnionych częściowo z redakcją rozgłośni), które przygotowano na wypadek wybuchu powstania w Polsce (opracowanych w kontekście wydarzeń na Węgrzech). Wskazówki te zobowiązywały RWE, aby przed wyborami m.in. nie nawoływać do bojkotu lub powstrzymywania się od udziału $\mathrm{w}$ wyborach, ale też nie zachęcać do głosowania oraz zaoferować „obiektywna prezentację" do takiego stopnia, do jakiego głosujący mogą wpłynąć na skład nowego parlamentu ${ }^{68}$.

Strona amerykańska rozumiała stanowisko kierownictwa PZPR na czele z Gomułką, które wyraźnie dawało do zrozumienia społeczeństwu, że nie ma szans na opuszczenie przez PRL obozu wschodniego. W takim kontekście pole manewru Polaków ograniczało się do wyboru między „zliberalizowanym narodowym reżimem komunistycznym a reżimem stalinowskim $w$ wydaniu takim jak poprzednio"69. Amerykanie jednocześnie dostrzegali, że o ile wcześniejsze wybory miały jedynie potwierdzać lojalność wobec władzy, o tyle teraz nowa ekipa oferowała jednak pewien program, który można odrzucić lub przyjąć. Wygrana gomułkowskiego kierownictwa umocniłaby jego pozycję międzynarodową i stworzyłaby na pewno klimat dla liberalizacji w pozostałych państwach regionu. Stanowiłaby jednocześnie pierwszy przypadek, że rząd komunistyczny poprzez wybory zyskałby autentyczne poparcie własnego społeczeństwa ${ }^{70}$.

Zdaniem amerykańskiego Departamentu Stanu, najgroźniejsze podczas wyborów dla władz z Warszawy byłyby demonstracje i rozruchy antykomunistyczne. Okoliczności takie skompromitowałaby Gomułkę poprzez zmuszenie go do użycia siły wobec społeczeństwa albo dały argument Kremlowi, że nie jest on w stanie zapanować nad sytuacją (stanowiłoby to pretekst do interwencji; nie wykluczano też zresztą możliwości radzieckiej prowokacji). Takie rachuby - jak informowały niektóre tytuły prasowe - wzbudzały niepokój w amerykańskich kręgach politycznych o przebieg głosowania. W najczarniejszych scenariuszach przewidywano nawet krwawe zajścia 20 stycznia, a to miałoby nieobliczalne konsekwencje dla całej sytuacji europejskiej. Ewentualne wystąpienia w Polsce mogły mieć bowiem następstwa w NRD w postaci buntu ludności przeciwko władzy. Do tak wywołanego konfliktu zaangażowałaby się wkrótce Republika Federalna Niemiec, z którą Waszyngton wiązały zobowiązania wynikające z Paktu Północnoatlantyckiego ${ }^{71}$.

Wobec powyższych obaw trudno się dziwić, że strona amerykańska była zadowolona zarówno ze spokojnego przebiegu głosowania, jak i jego wyników. Wskazywano, że wybory okazały się bezdyskusyjnym sukcesem Gomułki, ponieważ prawie wszy-

68 Za: J. Tyszkiewicz, Stany Zjednoczone wobec wyborów w Polsce..., s. 769; zob.: J. Nowak-Jeziorański, Polska z oddali. Wspomnienia, t. II 1956-1976, Kraków 1992, s. 13-14; P. Machcewicz, Emigracja w polityce międzynarodowej, Warszawa 1999, s. 176; idem, „Monachijska menażeria”. Walka $z$ Radiem Wolna Europa 1950-1989, Warszawa 2007, s. 124, 126.

69 M. Kula, op. cit., s. 193; Notatka Departamentu Stanu na temat wyborów w Polsce..., s. 305; Przeddzień wyborów w oczach amerykańskiego korespondenta, „Biuletyn Specjalny” PAP nr 3539/19.I.57.

70 Notatka Departamentu Stanu na temat wyborów w Polsce. 17 stycznia 1957 r..., s. 306.

71 M. Kula, op. cit., s. 193; Przed wyborami w Polsce, „Biuletyn Specjalny” PAP nr 3539/19.I.57. 
scy nowi członkowie parlamentu zostali przez niego „namaszczeni”72. Dyplomaci USA starali się jednocześnie zbadać motywy tak masowego uczestnictwa obywateli PRL w głosowaniu. Ambasador Joseph E. Jacobs przytaczał na przykład zebrane przez pracowników ambasady wypowiedzi przypadkowych osób (podwożonych samochodami), które wyjaśniały swój udział w wyborach rzekomym przymusem. Jacobs wskazywał ponadto, że wielu prostych ludzi tłumaczyło to tak, iż gdyby nie zagłosowali, i to nie zagłosowali bez skreśleń, to do PRL wkroczyliby Rosjanie ${ }^{73}$.

W Waszyngtonie dostrzegano znaczenie poparcia dla wyborów ze strony Kościoła katolickiego i uznawano to za kolejny dowód politycznej dojrzałości Polaków (uznających „narodowy komunizm” za mniejsze zło). Sekretarz Stanu John F. Dulles stwierdzał, że apetyt polskiego społeczeństwa na pogłębienie demokracji będzie stopniowo rósł, Gomułka zaś pójdzie w polityce zmian najpewniej tak daleko, jak tylko będzie mógł bez narażenia się na reperkusje ze strony Kremla. Szef amerykańskiej dyplomacji wyrażał znane już nadzieje, że polski przykład będzie także oddziaływał na pozostałem kraje komunistyczne. W takim kontekście sytuacja zaistniała w Polsce - jego zdaniem - mogła okazać się ważna dla kwestii zjednoczenia Niemiec. Departament Stanu wyrażał ponadto przekonanie, że zwycięstwo wyborcze pozwoli Gomułce przejąć kontrolę nad tymi ogniwami w partii, w których znaczące wpływy posiadali Natolińczycy ${ }^{74}$.

Wyrazem aprobaty rządu USA dla ewolucji stosunków politycznych w PRL, w tym wyborów do Sejmu, była zgoda na sprzedaż do PRL na warunkach kredytowych nadwyżek produktów rolnych, a także ułatwienie Polsce relacji handlowych ${ }^{75}$.

We Francji przemiany październikowe w PRL, w tym wybory sejmowe, nie znajdowały się w centrum zainteresowania. Co prawda procesy odwilżowe w $1956 \mathrm{r}$. wpłynęły na pewne ożywienie wzajemnych kontaktów, to jednak później na rozwoju polsko-francuskich stosunków politycznych zaciążył - absorbujący Paryż - kryzys sueski i pogorszenie na tym tle ogólnych relacji Francji z blokiem wschodnim (nieco lepiej wyglądała natomiast $\mathrm{w}$ tym czasie polsko-francuska wymiana kulturalna, naukowa oraz handlowa $)^{76}$.

Pomimo tego sytuacja w PRL była śledzona i analizowana przez francuskich dyplomatów. Ambasador Eric de Carbonnel zareagował na przemówienie Gomułki z 29 grudnia, które otwierało kampanię wyborczą, stwierdzając trafnie, że jego treść,

72 Za.: J. Tyszkiewicz, Otwarte okno w „żelaznej kurtynie”. Polityka administracji prezydenta Eisenhowera wobec Polski (październik 1956-styczeń 1961), Wrocław 2003, s. 56.

73 M. Kula, op. cit., s. 193.

74 Ibidem, s. 201.

75 J. Tyszkiewicz, Otwarte okno..., s. 56 i nn.; A. Mania, The National Security Council i amerykańska polityka wobec Europy Wschodniej 1945-1960, Kraków 1994, s. 159 i nn.

76 W maju 1956 r. do Paryża został nawet zaproszony premier Józef Cyrankiewicz, jednak jego wizyta, planowana na czerwiec, nie doszła ostatecznie do skutku z powodu rozruchów w Poznaniu i ich konsekwencji (M. Pasztor, Francja wobec października 1956 r. w Polsce, [w:] Polski październik 1956 w polityce światowej..., s. 267 i nn.). W kwietniu i maju 1956 r. PRL odwiedzali francuscy parlamentarzyści (eadem, Między Paryżem, Warszawa a Moskwą. Polityczne uwarunkowania stosunków polsko-francuskich, „Dzieje Najnowsze” 2002, nr 2, s. 58). 
w porównaniu z wystąpieniem przywódcy PZPR z VIII Plenum, była zachowawcza i podważała nadzieje zwolenników pogłębienia demokratyzacji w Polsce. Zdaniem ambasadora, Gomułka wyznaczał w ten sposób dopuszczalne granice procesów liberalizacji, przekonując jednocześnie Kreml do własnych zamierzeń umacniania socjalizmu i władzy partii ${ }^{77}$.

Dyplomaci francuscy obserwowali układanie list wyborczych do Sejmu konstatując, że poszczególne grupy społeczne w Polsce czuły się pominięte przy wyłanianiu kandydatów, co oczywiście wywoływało niezadowolenie. Na początku stycznia $1957 \mathrm{r}$. ambasador Carbonnel, na podstawie doniesień prasowych o atakach na niektórych kandydatów na posłów (także o charakterze antysemickim) stwierdzał, że stoją za tym albo środowiska prawicowe, albo działacze z okresu stalinowskiego, zagrożeni obecnie politycznym wykluczeniem (w ewentualnych kłopotach nowego kierownictwa widzący dla siebie szansę ponownego wypłynięcia). Zdaniem Francuza, kampania przed głosowaniem przebiegała w „,iężkiej atmosferze”, a wyborcy pogrążeni byli w apatii, o czym miała świadczyć opieszałość w sprawdzaniu list wyborczych ${ }^{78}$.

Wraz ze zbliżaniem się daty wyborów - jak dowodził Carbonnel - coraz wyraźniejsza stawała się ewolucja stanowiska Gomułki (widoczna już we wspomnianym przemówieniu z 29 grudnia). W wystąpieniu z 9 stycznia przywódca PZPR nie odnosił się już krytycznie do poprzedniej polityki, ale raczej bronił fundamentów systemu i przemian, jakie zaszły w Polsce po 1945 r.; odcinał się także wyraźnie od naśladowania modelu jugosłowiańskiego, co stanowiłoby taki sam błąd, jak wcześniej powielanie drogi radzieckiej (cenzura sprzeciwiała się krytykowaniu błędów stalinizmu czy podkreślaniu solidarności polsko-jugosłowiańskiej). Nakazem chwili miało być zwarcie szeregów partii i zapewnienie zwycięstwa jej kandydatów poprzez głosowanie bez skreśleń. „Zdaniem ambasadora, postawa Gomułki była dążeniem do odtworzenia jedności wokót PZPR. Gomulka reagowat w ten sposób wobec nie takiego jakby chciał przebiegu kampanii wyborczej; I sekretarz obawiał się - wedtug Carbonnela, że brak jednomyślności w trakcie wyborów wywoła zamieszanie, które opóźni odbudowe gospodarcza i osłabi pozycję PRL, jaką sobie zdobyła w ciagu kilku ostatnich miesięcy"79.

Francuzi przewidywali, że podczas samych wyborów w Polsce mogło dojść do rozruchów, na co wskazywał zwłaszcza konsul w Gdańsku. Ten sam dyplomata, jak wynikało z doniesień informatorów Służby Bezpieczeństwa, miał też wykazywać duże zainteresowanie przygotowaniami do głosowania. Zbierał na przykład informacje o kandydatach na posłów, wykorzystując do tego obywateli polskich, którym obiecywał w zamian wysokie wynagrodzenia. Konsul dopytywał zwłaszcza o przynależność partyjną i staż w PZPR poszczególnych kandydatów, a także o to, czy byli jakkolwiek prześladowani w okresie stalinowskim oraz jak wygląda ich obecna działalność ${ }^{80}$.

77 M. Kula, op. cit., s. 179.

78 Ibidem, s. 186-187, 191.

79 Cyt. za: ibidem, s. 188.

80 Archiwum Instytutu Pamięci Narodowej, Bu 00231/86, t. 133, Telefonogram nr 187/57 do v-ce ministra spraw wewnętrznych tow. Alstera, Gdańsk, dnia 19. 1. 1957 r., k. 189. 
Przed samymi wyborami ambasador Carbonnel wskazywał na złą sytuację gospodarczą Polski i pogłębiający się konflikt między skrzydłem liberalnym a konserwatywnym $\mathrm{w}$ partii. Istniało spore prawdopodobieństwo masowego skreślania kandydatów z pierwszych miejsc na listach, co mogło wynikać z prowincjonalnych partykularyzmów, potrzeby głosowania na nowe twarze, ale przede wszystkim wrogości wobec PZPR, na którą - jak słusznie konstatował ambasador - nie rozciągała się popularność Gomułki. Ten ostatni wniosek był też czytelny dla szerszej opinii publicznej we Francji, o czym świadczyły przekazy prasowe ${ }^{81}$.

Wyniki wyborów ambasada francuska uznała za osobisty sukces Gomułki, tym bardziej że nie zauważono stosowania przez władze większych środków bezpieczeństwa czy instrumentów przymusu. Masowa frekwencja i wyniki miały kilka przyczyn: siła przekonywania samego Gomułki i rzeczowość jego argumentów, stanowisko Radia Wolna Europa popierającego tryb głosowania bez skreśleń (co miało zamykać drogę restytucji stalinizmu, powrotu więzień politycznych czy interwencji radzieckiej) oraz postawa Kościoła katolickiego. Wskazywano jednak równocześnie, że ludzie mogli się też bać skutków braku udziału w głosowaniu. Przy czym chodziło tutaj nie tyle o konsekwencje ze strony państwa, ile o późniejsze następstwa w postaci odwrotu od dotychczasowych osiągnięć polskiego października „(...) wielu Polaków powiedziało nam, że woleliby wstrzymać się od głosowania lub podkreślać niektóre nazwiska, ale zdawali sobie doskonale sprawe jak porażka wyborcza p. Gomułki mogła być wykorzystana przeciw ich wolności" $"$.

Już z pewnej perspektywy ambasador Carbonnel stwierdzał, że Polacy poparli komunistów jedynie z powodów wyrozumowanych, a nie spontanicznych, gdyby zaś głosowanie było rzeczywiście wolne, to wyniki mogłyby być całkiem inne. Dyplomata nie podzielał jednocześnie wniosków wielu obserwatorów zachodnich, którzy reprezentowali pogląd, że nie było mowy o wolnych wyborach w PRL, skoro jedynie $10 \%$ wyborców skorzystało z kabin do głosowania. Jego zdaniem w sytuacji, gdy większość społeczeństwa zgadzała się na głosowanie bez skreśleń, to korzystanie $\mathrm{z}$ kabin było bezużyteczne ${ }^{83}$.

Wielka Brytania w $1956 \mathrm{r}$. nie miała większego wpływu na wydarzenia polityczne w Europie Wschodniej. Rząd tego państwa był usatysfakcjonowany faktem odprężenia w relacjach Wschód-Zachód, a przede wszystkim, tak samo jak władze francuskie, zaprzątnięty własnymi kłopotami związanymi z kryzysem sueskim. Uwagę

81 M. Kula, op. cit., s. 191-192; Prasa francuska o sytuacji w Polsce, „Biuletyn Specjalny” PAP nr 3539/19.I.57.

82 Cyt. za: M. Kula, op. cit., s. 194-195.

83 Ibidem, s. 196-198. Za wyraz akceptacji dla wyników wyborów, a szerzej, dla liberalizacji systemu w PRL po październiku 1956 r., można na pewno uznać powstanie wiosną 1957 r. we francuskim Zgromadzeniu Narodowym grupy przyjaźni francusko-polskiej, co doprowadziło m.in. do wizyty delegacji polskiego Sejmu we Francji w lutym 1958 r. (M. Pasztor, Między Paryżem, Warszawa i Moskwą. Stosunki polsko-francuskie w latach 1954-1969, Toruń 2003, s. 49-51). 
Brytyjczyków przyciągało bardziej powstanie na Węgrzech i radziecka interwencja w tym kraju, ale bieg wypadków w PRL był również bacznie obserwowany ${ }^{84}$.

Wspomniane przemówienie Gomułki z 29 listopada, początkujące kampanię wyborczą, interpretowano w Londynie podobnie jak w Paryżu. Zdaniem Brytyjczyków, przywódca PRL przecinał stanowczo nadzieje na dalsze zwiększenie swobód politycznych i dawał Polakom jasno do zrozumienia, że kończy się „miodowy miesiąc" w stosunkach rządu ze społeczeństwem; członków PZPR I sekretarz zapewniał jednocześnie, że partia bez żadnych wątpliwości zachowuje władzę w kraju ${ }^{85}$. Z kolei nacisk, jaki Gomułka kładł na zgodność z linią polityczną ZSRR był - według Londynu - skutkiem jego wizyty w Moskwie. Niebagatelne znaczenie miały również obawy I sekretarza, że kryzys w PZPR, w obliczu ciągłego fermentu, będzie się pogłębiał, a partia po prostu się rozsypie (wskazywano tutaj na grożące Gomułce silne wpływy frakcji natolińskiej w lokalnym aparacie PZPR) ${ }^{86}$.

Londyn nie miał większych złudzeń co do nadchodzących wyborów sejmowych w PRL i nie oczekiwał, że będą one w pełni demokratyczne. Jednak ambasador Eric Berthoud starał się dostrzec pozytywne zmiany w porównaniu do procedur wyborczych, stosowanych w innych państwach komunistycznych, jak i w poprzednich latach w Polsce. W grudniu 1956 r. podkreślano, że polski elektorat po raz pierwszy będzie miał jakąkolwiek możliwość wyboru, a kierownictwo partyjne w obliczu nacisku opinii publicznej - nie pozwoli sobie na pominięcie wielu kandydatów do przyszłego sejmu. Ambasador zwracał też uwagę, że stan nastrojów społecznych i interes polityczny nowej ekipy władzy spowoduje, że nie opłaci się jej wpływać na wyniki głosowania przez zastraszanie społeczeństwa czy też fałszerstwa. Przewidywano ponadto, że w wyłonionym sejmie może pojawić się partia reprezentująca środowiska katolickie ${ }^{87}$.

Brytyjscy dyplomaci śledzili kampanię wyborczą i dostrzegali krytykę, jaka w jej toku spadała na partię. W związku z apelem Gomułki o głosowanie bez skreśleń, konsul A. G. Evans z placówki w Gdyni (konsulat przeniesiono tutaj z Gdańska w 1955 r.) słusznie przewidywał, że większość Polaków usłucha prośby swojego przywódcy, a górę w tym przypadku weźmie polityczny realizm i obawa przed sowiecką interwencją. Jednocześnie wskazywano na pewną apatię polskiego społeczeństwa w trakcie kampanii. Z informacji, jakimi dysponował ambasador Berthoud, wynikało, że w Warszawie niewiele osób sprawdzało listy wyborcze i nie znało nazwisk kandydatów do sejmu ze swoich rejonów. Według dyplomaty, niewzięcie udziału

84 A. Deighton, Brytyjskie reakcje na wydarzenia w Polsce w okresie od czerwca do listopada 1956 r., [w:] Polski Październik 1956 w polityce światowej..., s. 235-237.

85 M. Kula, op. cit., s. 180.

$86 \mathrm{~W}$ kontekście tego przemówienia ambasada brytyjska wskazywała, że na Zachodzie rozpowszechniony był z gruntu fałszywy obraz Gomułki, w którym usiłowano widzieć bardziej socjaldemokratę niż komunistę (nierealistyczne było też widzenie tzw. „gomułkowskiej drogi do socjalizmu” jako demokratycznej w zachodnim sensie tego słowa (ibidem, s. 180-182).

87 J. Tebinka, Nadzieje i rozczarowania. Polityka Wielkiej Brytanii wobec Polski 1956-1970, Warszawa 2005, s. 61; M. Kula, op. cit., s. 186. 
w głosowaniu nie groziło już teraz niebezpiecznymi konsekwencjami, jak podczas poprzednich wyborów z 1952 r., a mogło stanowić wyraz postawy wobec systemu i braku wiary w nowy parlament. Wobec tego Berthoud przypuszczał, że frekwencja może wynieść $60-70 \%$, choć zastrzegał, że w złożonych polskich warunkach żadne z przewidywań może się nie sprawdzicic ${ }^{88}$.

Wraz ze zbliżaniem się daty wyborów coraz częściej na ich temat pisała brytyjska prasa. W styczniu 1957 r. o kampanii wyborczej w Polsce informowały na bieżąco m.in. dzienniki „Daily Telegraph”, „Times”, „Manchester Guardian”. W tym ostatnim 18 stycznia ukazał się komentarz redakcyjny pod znamiennym tytułem „Dziwny wybór”, gdzie stwierdzano, że „Naród polski po raz pierwszy od dziesięciu lat ma autentyczną, choć ograniczoną okazję wybrania przedstawicieli, którzy będą rzeczywistymi reprezentantami społeczeństwa w parlamencie. Podkreślano jednocześnie, że gdyby Polacy mieli możliwość rzeczywistego wyboru, zgodnego z ich sumieniem i przekonaniami, to po prostu odrzuciliby komunizm, nawet ten częściowo zreformowany. Jednak w obliczu wydarzeń na Wegrzech - jak dowodzono - obywatele PRL zdali sobie sprawe ,jaka katastrofę moga pociagnąc za soba usiłowania zrzucenia kontroli partii $w$ kraju znajdujacym się pod dominacja radziecka”89. Z kolei magazyn „New Statesman and Nation” w artykule „Drugi kryzys Gomułki” stwierdzał, że „Wybory powszechne w Polsce moga równie dobrze doprowadzić do kryzysu o wiele poważniejszego niż dni październikowe, ponieważ w kraju tym nie rozwiązano dotychczas $\dot{z}$ adnego problemu". Nowemu kierownictwu partyjnemu udało się jedynie złagodzić część nastrojów rewolucyjnych i antyradzieckich. Jednak w wypadku, gdyby na skutek wyborów „przeszła nie komunistyczna większość kandydatów do sejmu, $z$ powodzeniem mogłoby to przekonać Rosjan, że Gomulka utracił kontrolę i stanowiłoby to dla nich pretekst dla interwencji, by uchronić Polskę od kontrrewolucji" ${ }^{90}$.

Duże zainteresowanie polskimi wyborami wykazywały brytyjskie środowiska katolickie. Wśród komentarzy podkreślano, że tego typu sytuacja ma miejsce w państwie wschodnioeuropejskim po raz pierwszy od zakończenia wojny, kiedy jego kierownictwo oświadczyło publicznie, iż "parlament powinien być najwyższa władza polityczną". Oczywiście nie spodziewano się detronizacji rządzącej PZPR i zdawano sobie sprawę, że Polska w dalszym ciągu pozostaje krajem komunistycznym, zależnym od ZSRR, w którym parlament jest kontrolowany, a nie sprawuje kontroli nad władzą wykonawczą, spoczywającą niepodzielnie w ręku partii. Mimo to - jak argumentowano - obywatele będą mieli okazję dokonać wyboru, ponieważ umożliwia im to nowa ordynacja i jest to znaczny postęp w porównaniu z 1952 rokiem. Snuto też optymistyczne prognozy, że wybory w PRL „stana się wzorem dla analogicznych wyborów w innych krajach komunistycznych". Natomiast najistotniejszym prawdopodobnie wynikiem polskiego głosowania będzie usunięcie najbardziej

88 M. Kula, op. cit., s. 190-191.

89 Przed wyborami w Polsce. Głosy prasy brytyjskiej z 18 bm., „Biuletyn Specjalny” PAP nr 3539/19.I.57.

90 Ibidem. 
skompromitowanych stalinowców. Katoliccy kandydaci stanowili wprawdzie tylko 3\% spośród 729 zgłoszonych, ale wszyscy - według tygodnika „Katholic Times” - mają „dobre widoki na znalezienie się wśród 459 posłów wybranych do Sejmu”"1.

Dyplomaci brytyjscy obserwowali oczywiście przebieg wyborów i dość pozytywnie oceniali ich organizację. Londyn nie kwestionował również prawdziwości danych na temat wysokiej frekwencji (94\%) oraz dużego poparcia dla kandydatów FJN. Powszechny udział w głosowaniu oceniano jako skutek stanowiska Kościoła katolickiego, który zachęcał do uczestnictwa oraz intensywnych zabiegów ze strony władz, łącznie z wieczornymi wizytami członków komisji wyborczych w domach obywateli. Pracownicy ambasady odwiedzali także poszczególne lokale wyborcze. Stwierdzali, że panowała tam dobra atmosfera i nie było nacisku na uczestników aktu wyborczego. Dodawano jednak, że głosujący, pamiętający poprzednie wybory z 1952 r. i słuchający natarczywych wezwań Gomułki do wrzucania kart bez skreśleń, mogli obawiać się korzystania $\mathrm{z}$ kabin do głosowania (według obliczeń brytyjskich dyplomatów $\mathrm{w}$ wizytowanych lokalach do kabin wchodziło zaledwie 5 do $20 \%$ osób $)^{92}$.

Wyrazem pozytywnego stosunku Londynu do wyborów był fakt uczestnictwa brytyjskiego ambasadora w inauguracyjnym posiedzeniu sejmu, które odbyło się 20 lutego 1957 roku. W Foreign Office rozważano także projekt wymiany delegacji między parlamentami obydwu państw (miała to być alternatywa dla wizyty brytyjskich ministrów, którą w dalszym ciągu uważano za przedwczesną) ${ }^{93}$.

Warto wspomnieć, że wydarzenia roku 1956 w Polsce oraz wybory do Sejmu były na Zachodzie przedmiotem obserwacji również instytucji ponadnarodowych. Najważniejsze znaczenie miał tutaj oczywiście Pakt Północnoatlantycki. Analitycy sojuszu uznawali polskie wybory za ważny test nowej ekipy władzy pod przywództwem Gomułki. Konstrukcję ordynacji wyborczej (faworyzującej kandydatów partii), spokój społeczny podczas głosowania oraz poparcie ze strony Kościoła katolickiego interpretowano jako wolę uniknięcia losu Węgier. Powodzenie koncepcji głosowania bez skreśleń obserwatorzy z NATO tłumaczyli jako osobisty sukces i wzmocnienie pozycji przywódcy PZPR wobec przeciwników z konserwatywnego skrzydła w partii $^{94}$.

\section{Podsumowanie}

Wybory do Sejmu PRL ze stycznia 1957 r., przeprowadzone w jeszcze nieprzebrzmiałej, burzliwej atmosferze przemian październikowych, miały swój szeroki oddźwięk poza granicami Polski - zarówno w tzw. obozie socjalistycznym, jak i na

91 Katolicy brytyjscy wobec wyborów w Polsce, „Biuletyn Specjalny” PAP nr 3539/19.I.57.

92 M. Kula, op. cit., s. 190-191; J. Tebinka, op. cit., s. 61.

93 J. Tebinka, op. cit., s. 62.

94 Za: R. Kupiecki, NATO wobec wydarzeń października 1956 r. w Polsce, [w:] Polski Październik 1956 w polityce światowej..., s. 293; idem, Polska lat pięćdziesiątych w raportach zachodnich organizacji polityczno-wojskowych, [w:] Niepiękny wiek XX, red. B. Brzostek, J. Eisler, D. Jarosz, K. Kosiński, T. Wolsza, Warszawa 2010, s. 442. 
Zachodzie. W Związku Radzieckim i podporządkowanych mu państwach Europy Środkowowschodniej, żywiołowa kampania oraz nieprzewidywalny wynik głosowania rodziły poważny niepokój. Zapowiadany przez władze PRL tryb wyłonienia nowego sejmu i towarzyszące temu wrzenie społeczne, identyfikowano jednoznacznie jako ciąg dalszy „polskiej anarchii” $i$ „pokojowej kontrrewolucji”, które na jesieni 1956 r. spędzały sen z powiek komunistycznych liderów. Mimo że polskim wyborom niezmiernie daleko było do standardów „normalnej” demokracji, to i tak dla Berlina Wschodniego, Pragi czy Tirany stanowiły one zaprzeczenie stalinowskiego kanonu plebiscytowo-fasadowej „demokracji ludowej”. Obawiano się, że w razie przegranej PZPR, ekipie Gomułki, której przecież i tak nie ufano, nie uda się zapanować nad sytuacją polityczną, a PRL pogrąży się w chaosie, co przyniesie trudne do przewidzenia konsekwencje dla całego obozu. W takich okolicznościach wyniki głosowania $\mathrm{w}$ Polsce przyjęto $\mathrm{z}$ widoczną ulgą, chwaląc już teraz polskie kierownictwo za umiejętną politykę i podkreślając wagę wyborczego zwycięstwa PZPR. Przypuszczać też można, że niektórzy przywódcy tzw. demoludów mogli odczuwać swego rodzaju zazdrość, patrząc na rzeczywiste poparcie, jakim podczas wyborów obdarzała Gomułkę znaczna część społeczeństwa PRL.

Inaczej wybory sejmowe w Polsce odbierano w Jugosławii i Chinach. Belgrad popierał Warszawę dostrzegając w wyborach słuszność idei różnych dróg do socjalizmu, która stała się przecież głównym powodem jego konfliktu z Moskwą pod koniec lat 40. i odcięcia się Jugosławii od zdominowanego przez ZSRR bloku wschodniego. Z kolei stanowisko ChRL wobec wyborów w Polsce, tak jak i całokształtu przemian w PRL, było już elementem szerszej rozgrywki z Kremlem o przodownictwo w ruchu komunistycznym. Pekin starał się więc patronować ekipie Gomułki, ale pomny przykładu Węgier, nie chciał dalszej destabilizacji w radzieckiej strefie dominacji. Przede wszystkim więc $z$ tego względu wynikała pomoc KPCh dla PZPR w kampanii wyborczej (wizyta Zhou Enlaia), przez co chciano umocnić własne wpływy w perspektywie przyszłej ideologicznej batalii z ZSRR.

Główne państwa Zachodu postrzegały wydarzenia 1956 r. w Polsce, w tym także wybory, przez głębszy pryzmat ówczesnych relacji z blokiem radzieckim. Stany Zjednoczone widziały w Gomułce przywódcę, który będzie dążył do większej samodzielności względem Kremla („drugi Tito”) i że podobne tendencje - jak kalkulowano - wystąpią z czasem w innych krajach podporządkowanych ZSRR ${ }^{95}$. $\mathrm{W}$ proces ten wpisywały się polskie wybory, które, pomimo swoich niedoskonałości, poszerzały margines społecznej aktywności i wzmacniały na zewnątrz ekipę Gomułki. Francja i Wielka Brytania, choć zaabsorbowane własnymi problemami (kryzys sueski), analizowały wnikliwie sytuację polityczną w PRL. Podczas kampanii wyborczej w Paryżu i Londynie właściwie odczytywano zarówno nastroje społeczne panujące w Polsce, jak i intencje rządzących. Wyniki głosowania interpretowano jako osobiste osiągnięcie Gomułki, ale i efekt rozsądku, czy może bardziej realizmu, samych Polaków.

95 Zob.: J. Tyszkiewicz, Stany Zjednoczone wobec wyborów w Polsce..., s. 768. 


\section{Foreign echoes of the Polish parliamentary elections of 20 January 1957}

The parliamentary elections of 1957 were a consequence of the Polish October Revolution and echoed on both sides of the Iron Curtain. In the USSR and in its zone of dominance, the outcome of the vote aroused serious concern, as the new system of election to the Sejm, and, above all, the accompanying social unrest, were unambiguously identified as yet another development of the "anarchy in Poland". It was feared that, should the Workers' Party lose, the already distrusted Gomulka's team would be unable to retain control over the political situation and the Polish People's Republic would plunge into chaos, which then would bring unpredictable consequences for the entire bloc. In such circumstances, the outcome of the vote was received with obvious relief; the Polish authorities were now praised for their skillful politics, and the importance of the electoral success of the Polish United Workers' Party was strongly emphasised.

But those results were judged differently in Yugoslavia and China. The authorities in Belgrade were supportive of Poland, as they defended the concept of different paths towards socialism, which had become a core reason of their conflict with Moscow in the late 1940s and Yugoslavia's split with the Eastern bloc dominated by the Soviet Union. In turn, the Chinese stance on the elections in Poland, as well as the overall changes in the Polish People's Republic, resulted from a wider rivalry with the Kremlin regarding leadership of the communist movement. The authorities in Beijing therefore tried to influence Gomułka's team, but mindful of the case of Hungary, they preferred to avoid further destabilisation within the Soviet sphere of domination.

At the same time, major Western countries perceived the Polish events of 1956, including the subsequent elections, through a deeper context of current relations with the Eastern Bloc. The US saw Gomułka as a leader who would strive for greater autonomy in relations with the Kremlin (a "second Tito"), and hoped that similar trends would occur over time in other countries subordinated to the Soviet Union. France and the United Kingdom, although focusing on their own problems (the Suez Crisis), followed the political situation in Poland very closely. During the electoral campaign, Paris and London were quite accurate in their interpretation of the public sentiment and the intentions of the authorities in Poland. The results of the vote were seen as Gomułka's personal success, but also as a voice of reason, or perhaps realism, of the Poles themselves.

Translated by Jakub Perliński

\section{Иностранные отголоски выборов в Сейм ПНР 20 января 1957 года}

Выборы в Сейм ПНР в 1957г. были последствием перемен Польского Октября и нашли широкий отклик по обеим сторонам Железного занавеса. В СССР и странах его зоны доминирования результат голосования вызвал серьезное беспокойство, так как заранее объявленный порядок избрания нового парламента, а прежде всего, сопровождавшее его социальное волнение, было однозначно идентифицировано, как продолжение «польской анархии». Были опасения, что в случае проигрыша ПОРП, команде Гомулки, которой ведь итак не доверяли, не удастся овладеть политической обстановкой, а ПНР погрузится в хаос, что принесет непредсказуемые последствия для всего блока. При таких обстоятельствах, результаты голосования в Польше были приняты с явным облегчением, теперь уже восхваляя польское руководство за умелую политику и отмечая весомость победы ПОРП на выборах.

По-другому выборы в Сейм в ПНР воспринимались в Югославии и Китае. Белград поддерживал Варшаву, замечая в выборах правильность идеи о разных путях к социализму, которая же стала главной причиной его конфликта с Москвой в конце 1940-х гг. и отмежевания Югославии от подчиненного СССР восточного блока. Позиция Китая, каса- 
тельно польских выборов, также как и перемен в ПНР в целом, в свою очередь, являлась элементом более широкой игры с Кремлем о первенство в коммунистическом движении. Пекин пытался покровительствовать команде Гомулки, но помня о примере Венгрии, не хотел дальнейшей дестабилизации в советской зоне влияния.

Западные державы воспринимали происшествия 1956г. в Польше, включая и выборы, сквозь более глубокую призму тогдашних отношений с советским блоком. Соединенные Штаты видели в Гомулке руководителя, который будет стремиться к большей самостоятельности по отношению к Кремлю («второй Тито») и надеялись, что похожие тенденции появятся со временем в других странах, подчиненных СССР. Франция и Великобритания, хотя были поглощены собственными проблемам (Суэцкий кризис), тщательно анализировали политическую обстановку в ПНР. В Париже и Лондоне правильно угадали так общественное настроение, господствующее в Польше во время предвыборной кампании, как и намерения руководителей. Результаты голосования интерпретировались как личное достижение Гомулки, но и как следствие благоразумия, или, скорее, реализма самих поляков.

Перевод Агнешка Поспишьль

\section{Bibliografia}

Centrum władzy Protokoły posiedzeń kierownictwa PZPR. Wybór z lat 1949-1970, „Dokumenty do dziejów PRL”, oprac. A. Dudek, A. Kochański, K. Persak, Warszawa 2000, z. 13.

Deighton A., Brytyjskie reakcje na wydarzenia w Polsce w okresie od czerwca do listopada 1956 r., [w:] Polski Październik 1956 w polityce światowej, red. J. Rowiński, Warszawa 2006.

Dokumenty programowe polskiego ruchu robotniczego 1878-1984, red. N. Kołomejczyk, B. Syzdek, Warszawa 1986.

Dziak W. J., Albania między Belgradem, Moskwa i Pekinem, Warszawa 1991.

Dzieje Sejmu Polskiego, Warszawa 2011.

Friszke A., Polska. Losy państwa i narodu 1939-1989, Warszawa 2003.

Historia sejmu polskiego, t. III: Polska Ludowa, red. A. Ajnenkiel, Warszawa 1989.

Kampania wyborcza i wybory do Sejmu 20 stycznia 1957, wybór, wstęp i opracowanie P. Machcewicz, Warszawa 2000.

Korzon A., Pierwszy Raport Ambasadora PRL w Moskwie Tadeusza Gedego (1957 r.), „Dzieje Najnowsze" 1999, nr 4.

Kraczkowski R., Sejm w okresie PRL, [w:] Dzieje Sejmu Polskiego, Warszawa 2011.

Kula M., Paryż, Londyn i Waszyngton patrza na Październik 1956 r. w Polsce, Warszawa 1992.

Kupiecki R., NATO wobec wydarzeń października 1956 r. w Polsce, [w:] Polski Październik 1956 w polityce światowej, red. J. Rowiński, Warszawa 2006.

Kupiecki R., Polska lat pięćdziesiątych w raportach zachodnich organizacji polityczno-wojskowych, [w:] Niepiękny wiek XX, red. B. Brzostek, J. Eisler, D. Jarosz, K. Kosiński, T. Wolsza, Warszawa 2010.

Labor E., Der Rapacki - Plan und die DDR. Die Entspannungsvision des polnischen Außenministers Adam Rapacki und die deutschlandpolitischen Ambitionen der SED-Führung in den fünfziger und sechziger Jahren, Berlin 2003.

Łoś R., Polska-ZSRR 1956, Łódź 1999.

Machcewicz P., Emigracja w polityce międzynarodowej, Warszawa 1999.

Machcewicz P., „Monachijska menażeria”. Walka z Radiem Wolna Europa 1950-1989, Warszawa 2007.

Mania A., The National Security Council i amerykańska polityka wobec Europy Wschodniej 1945-1960, Kraków 1994.

Mażewski L., Dyskusja na temat reformy ustroju Polskiej Rzeczypospolitej Ludowej w latach 1956-1957, „Czasopismo Prawno-Historyczne” 2010, z. 1. 
Mołdawa T., Sejm Polskiej Rzeczypospolitej Ludowej, [w:] Historia sejmu polskiego, t. III: Polska Ludowa, red. A. Ajnenkiel, Warszawa 1989.

Nowak-Jeziorański J., Polska z oddali. Wspomnienia, t. II: 1956-1976, Kraków 1992.

Pasztor M., Między Paryżem, Warszawa a Moskwą. Polityczne uwarunkowania stosunków polsko-francuskich, „Dzieje Najnowsze” 2002, nr 2.

Pasztor M., Między Paryżem, Warszawą i Moskwą. Stosunki polsko-francuskie w latach 1954-1969, Toruń 2003.

Pasztor M., Francja wobec października 1956 r. w Polsce, [w:] Polski Październik 1956 w polityce światowej, red. J. Rowiński, Warszawa 2006.

Paździora M., Międzynarodowy ruch komunistyczny wobec polskiego października 1956, [w:] Przełomowy rok 1956. Poznański Czerwiec Polski Październik. Budapeszt. Materiały międzynarodowej konferencji naukowej. Poznań, 26-27 czerwca 1996 r., red. E. Makowski i S. Jankowiak, Poznań 1998.

Pełczyński Z., Polska droga od komunizmu. Refleksje nad historia i polityka 1956-2006, Warszawa 2007.

Persak K., Kryzys stosunków polsko-radzieckich w 1956 r., [w:] Polska 1944/45-1989. Polska 1956 - próba nowego spojrzenia, Studia i Materiały, t. III, Warszawa 1997.

Polska 1944/45-1989. Polska 1956 - próba nowego spojrzenia, Studia i Materiały, t. III, Warszawa 1997.

Polska - Niemcy Wschodnie 1945-1990. Wybór dokumentów, red. J. Kochanowskiego i K. Zemera, t. 3, lata 1956-1957, Warszawa 2008.

Polski Październik 1956 w polityce światowej, red. J. Rowiński, Warszawa 2006.

Polskie Dokumenty Dyplomatyczne 1957, red. K. Ruchniweicz, T. Szumowski, Warszawa 2006.

Przełomowy rok 1956. Poznański Czerwiec Polski Październik. Budapeszt. Materiały międzynarodowej konferencji naukowej. Poznań, 26-27 czerwca 1996 r., red. E. Makowski i S. Jankowiak, Poznań 1998.

Ruchniewicz K., Warszawa - Berlin - Bonn. Stosunki polityczne 1949-1958, Wrocław 2003.

Shen Zhihua, Li Danhui, Kryzys w Polsce 1956 r. i stosunki polsko-chińskie widziane z Pekinu, [w:]

Polski Październik 1956 w polityce światowej, red. J. Rowiński, Warszawa 2006.

Skrzypek A., Mechanizmy uzależnienia Stosunki polsko-radzieckie 1944-1957, Pułtusk 2002.

Sowa A. L., Historia polityczna Polski 1944-1991, Kraków 2011.

Syzdkowie E. i B., Cyrankiewicz. Zanim zostanie zapomniany, Warszawa 1996.

Szczepańska A., Warszawa-Praga 1948-1968. Od nakazanej przyjaźni do kryzysu, Szczecin 2011.

Szumiło M., Roman Zambrowski 1909-1977. Studium z dziejów elity komunistycznej w Polsce, Warszawa 2014.

Tebinka J., Nadzieje i rozczarowania. Polityka Wielkiej Brytanii wobec Polski 1956-1970, Warszawa 2005.

Tischler J., I do szabli... Polska i Węgry. Punkty zwrotne $w$ dziejach obu narodów w latach 1956 oraz 1980-1981, Warszawa 2001.

Tischler J., Polski październik a Wegry, [w:] Polski Październik 1956 w polityce światowej, red. J. Rowiński, Warszawa 2006.

Tyszkiewicz J., Otwarte okno w „żelaznej kurtynie”. Polityka administracji prezydenta Eisenhowera wobec Polski (październik 1956-styczeń 1961), Wrocław 2003.

Tyszkiewicz J., Stany Zjednoczone wobec wyborów w Polsce 1947 - 1957 - 1989, [w:] Wybory i referenda $w$ PRL, red. M. Ligarski i M. Siedziako, Szczecin 2014.

Wybory i referenda w PRL, red. M. Ligarski i M. Siedziako, Szczecin 2014.

Żaryn J., Dzieje Kościoła katolickiego w Polsce (1944-1989), Warszawa 2003.

Robert Skobelski - dr hab., profesor w Instytucie Historii Uniwersytetu Zielonogórskiego, autor lub współautor kilku monografii i kilkudziesięciu artykułów naukowych z zakresu najnowszej historii Polski. (r.skobelski@ih.uz.zgora.pl) 